Fakultät III

Wirtschaftswissenschaften, Wirtschaftsinformatik und Wirtschaftsrecht

Volkswirtschaftliche Diskussionsbeiträge

Discussion Papers in Economics

No. $193-21$

May 2021

Alexander Stöcker

Partisanship in a Young Democracy:

Evidence from Ghana 


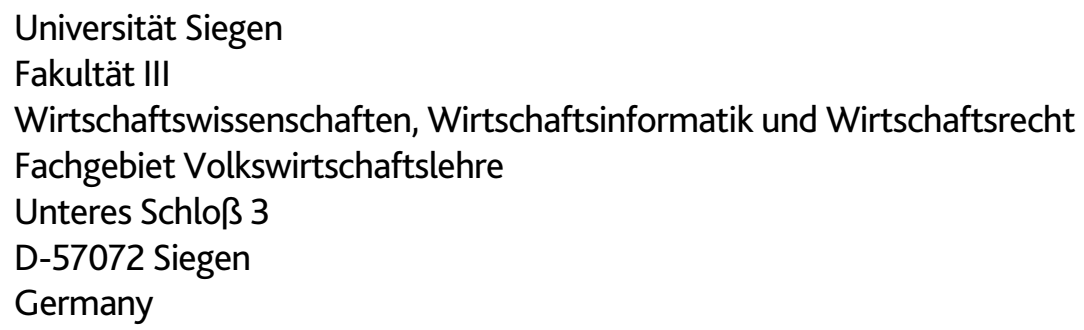

Available for free from the University of Siegen website at http://www.wiwi.uni-siegen.de/vwl/research/diskussionsbeitraege/

Discussion Papers in Economics of the University of Siegen are indexed in RePEc and can be downloaded free of charge from the following website: http://ideas.repec.org/s/sie/siegen.html 


\title{
Partisanship in a Young Democracy: Evidence from Ghana
}

\author{
Alexander Stoecker (University of Siegen) ${ }^{1}$
}

May 2021

\begin{abstract}
While past studies have put forward many reasons why partisanship in young African democracies should be considered weak and meaningless, this paper casts doubt on this notion by presenting evidence that suggests the presence of strong and stable patterns of partisanship in ordinary citizens. Based on survey data from Ghana, I exploit the variation introduced by the political turnovers of 2008 and 2016, estimating a partisan divide for a wide range of perceptions and attitudes. The results suggest that partisanship is both meaningful and prompts motivated reasoning among citizens, while also being indicative of increased polarization and thus a potential threat to effective governance. Furthermore, the analysis of attitudes towards democratic principles uncovers a worrying double standard that could negatively affect efforts towards the consolidation of democracy. A simple heterogeneity analysis reveals that while partisan identities seem to exist alongside ethnic identities, the latter still strongly determines the strength of party attachment in Ghana. Future research on political behavior needs to acknowledge the presence of these partisan motives and continue to investigate the impact of partisanship on the further development of democratic institutions in African democracies.
\end{abstract}

Keywords Partisan Divide, Public Opinion, Democratization, Africa, Ghana

\footnotetext{
${ }^{1}$ Department of Economics, Unteres Schloß 3, 57072 Siegen, Germany, email: alexander.stoecker@unisiegen.de. I am grateful to Thushyanthan Baskaran, Patrick Hufschmidt, Zohal Hessami and Jeff Conroy-Krutz as well as participants of the EPCS Meeting 2019, the MAGKS Seminar and the brownbag seminar at the University of Siegen for helpful comments. There are no potential conflicts of interest to declare.
} 


\section{Introduction}

For some time now, the literature on economic development has assigned a large portion of the attention to the issue of governance as one of the deep determinants of long-term development (Acemoglu et al. 2005). Basing the political system on a democratic foundation has long been regarded as a requirement for effective governance. With the third wave of democratization, elections and multi-party politics started flourishing in Africa and now almost seem to represent the new norm. Naturally with this development the importance of parties as the main players in the political arena has grown and nowadays African voters seem to be eagerly displaying their party preferences, not only during campaign season. But how does this affiliation with political parties compare to partisanship in established democracies, where it is seen as a form of social identity (Green et al. 2004, Huddy and Bankert 2017). It is generally believed that meaningful identities build at a young age and over a long period of time, while they can be facilitated when they are based on distinct social values or are even part of a sophisticated ideology (Downs 1957, Lupu 2012, Parker and Janoff-Bulman 2013). However, parties in Africa tend to be both young and lacking such a distinct ideological foundation. Hence, until recently the literature on Africa mostly ignored partisanship in their theories, reducing it to a strategy to benefit from patronage or merely a proxy for other existing identities such as religion or ethnicity (Cho and Bratton 2005, Bratton et al. 2011). Are African citizens able to align their opinions consistently with their partisan affiliation, hence does it imply a partisan identity? Or is their attachment without substance and solely dependent on the preferential treatment with resources?

In this paper, I provide evidence for the presence of stable partisan motives in Ghanaian citizens. Exploiting the variation in political opinions following political turnovers, I show that a large partisan divide exists. This partisan divide runs like a common thread through the analysis of a wide range of different performance assessments, trust, political and nonpolitical perceptions and even some attitudes towards democratic principles. Furthermore, the evidence in this paper suggests that partisan identities are distinct from ethnic identities, but the strength of partisan attachment is still significantly informed by ethnicity. These findings can be seen as a disconcerting sign regarding the consolidation of democracy, while the consistency of the partisan divide implies that partisan identities are meaningful and go along with motivated reasoning.

This study makes three principal contributions to the understanding of the political behavior of ordinary citizens in Sub-Saharan Africa. First, it complements the recent contributions to the literature that recognize the genuine presence of partisan identities in the young African democracies, thus underlining the need to account for partisan motives when investigating political behavior in Africa. Second, it suggests that the impact of partisanship on the consolidation process of democratic institutions needs to be critically assessed. And lastly, it provides further understanding on the relationship between partisan and ethnic identities. 
Before presenting more details on the design of the study in section 3, the following section will provide an overview of the theoretical underpinnings of partisanship and how they relate to Africa. Section 4 will then reveal and discuss the paper's findings before I shortly conclude.

\section{Theory of Partisanship}

\subsection{Partisan Motivation and Political Behavior}

The presence of partisanship has long been recognized as a major aspect of what governs political perceptions and attitudes and therefore ultimately political behavior (Campbell et al. 1960). In The American Voter - the seminal study of political behavior - Campbell and his colleagues establish a model of voter behavior that attributes partisan loyalties a paramount and causal role in the shaping of political attitudes. In their words, party identification "raises a perceptual screen through which the individual tends to see what is favorable to his partisan orientation" (Campbell et al. 1960, p. 133). In contrast some scholars have argued that partisanship is rather based on retrospective evaluations of party performances, i.e. a "running tally" model (Fiorina 1981, Gerber and Green 1999). However, this view has very much fallen out of favor following more recent contributions that demonstrate the decisive role of partisan identities in perpetuating distinct differences in opinions among ordinary citizens (Bartels 2002, Logan et al. 2003, Tverdova 2011, Anduiza et al. 2013, Blais et al. 2015). This finding is further based on the observation that people prefer information that are congenial to their partisan predispositions and resist information that are in contrast to their political ideology (Zaller 1992, Taber and Lodge 2006, Highton 2012). Hence, some scholars assign partisanship the role of a simple heuristic to facilitate the processing of complex information (Sniderman et al. 1991, Anderson and Tverdova 2003). This suggests that such biased information processing does not bode well for citizens' ability to accurately assess political performance and hold their leaders accountable. In fact, many studies have shown that perceptions very often deviate considerably from reality (Olken 2009, Gaines et al. 2007). Accordingly, this can serve as an explanation for why citizens regularly fail to punish underperforming politicians at the ballot boxes, even in cases where enough information on their respective behavior is available. Due to partisan predispositions, such new information is seen as less credible and gets adjusted accordingly, a process called motivated reasoning.

\subsection{Partisanship in Africa}

As the literature on partisanship is mostly based on established democracies, the question arises on how applicable its findings are on the decidedly different context of the new democracies in Sub-Saharan Africa. Certainly, almost all political systems on the African continent are characterized by a presidential system, often with plurality voting rules that 
naturally restrict the number of influential parties, thus lending some support to the applicability of the "Michigan model". Furthermore, the formation of partisanship among citizens may be facilitated by a sense of competition between different social groups in a society, an aspect that is certainly of relevance for the majority of countries in their postindependence history. Evidence suggests that individuals can segregate themselves into groups quite easily when they are pinned against each other (Chen and Li 2009, Kranton et al. 2013). The opinions collected in the Afrobarometer surveys show that the majority of African citizens feel attached to a party and their share has been increasing over time.

Still, in the African context, partisanship has hitherto been analyzed in a much different light, presumably only being used strategically by citizens to maximize their rents or solely representing other identity-establishing characteristics such as ethnicity or religion (Cho and Bratton 2005, Bratton et al. 2011). The argument for the presence of such weak partisan identities relies on the specific circumstances of the new African democracies. As mentioned before, partisan identities are believed to establish themselves at a young age, thus implying that mass partisanship within society only develops gradually across multiple generations. In the form of a stylized fact, the general pattern emerges that younger democracies tend to have a lower presence of partisanship among its citizens (Huber et al. 2005, Mainwaring and Zoco 2007, Dalton and Weldon 2007). The relative youth of African democracies and its parties should thus make it more difficult for them to establish strong partisan bases. Individuals also tend to form stronger partisan attachments to groups, when these are based on profound social values or more elaborate ideologies (Downs 1957, Lupu 2012, Parker and Janoff-Bulman 2013). Parties founding their policy programs coherently on these social values or ideologies can expect stronger ties from their supporters. Parties in Africa, however, do not appear to establish such coherent policy programs, making their proposed social or economic policies less distinguishable (Ferree 2006, Conroy-Krutz and Lewis 2011). Considering that education is believed to lay the foundation for the manifestation of a partisan identity (Joselyn and Haider-Markel 2014), the generally lower levels of formal education in most African countries might suggest that the average African citizen is less able to form such partisan identities in order to indulge in motivated reasoning. Accordingly, the empirical question arises if party preferences in African citizens are comparable to those studied extensively in more established democracies. In this regard, Carlson (2016) provides compelling evidence from Uganda that partisanship in Africa indeed needs to be seen as equivalent to partisanship in the West, as it entails a meaningful social identity and actually is characterized by motivated reasoning.

Beyond the mere presence of partisan identities and their likely impact on political accountability, their influence on opinions towards the democratic system is another important aspect to consider. While there are signs of general support for democracy in Africa, a better understanding of the nature of this support is instrumental. In their casebased and largely descriptive analysis of attitudes towards democracy, Bratton and Mattes 
(2001) try to provide insights into this debate and content that the majority of Africans rather thinks instrumentally about democracy and this will remain so for the foreseeable future. Despite evidence of generally broad support for democracy, citizens are much less satisfied with its concrete achievements, and this support is more strongly linked to the provision of political rather than economic goods. Both of which the authors interpret at least as some sign for intrinsic valuation. Unfortunately, their study does not address the impact of partisanship explicitly. Logan et al. (2003) are generally in line with these findings, further noting that while support for democracy seems to be strongly related to the partisan affiliation of respondents, there appears to be no considerable partisan divide on their commitment to democratic principles or national identity. In their comprehensive analysis on voting behavior in Africa, Bratton et al. (2011) attest that economic trump ethnic motives in voting intentions, while also recognizing a strong presence of partisan considerations. They, however, fail to clearly disentangle the interaction between economic and partisan motives.

\subsection{The Case of Ghana}

Since most countries in Sub-Saharan Africa have a relatively short and unstable democratic history, the party landscape has been described as fragmented and lacking stability and any meaningful form of ideology (Van de Walle and Butler 1999, Mozaffar and Scarritt 2005). At a first glance, Ghana is often seen as an exceptional case in this regard due to its unique political history since independence (Osei and Malang 2018, Elischer 2012). Since its return to democracy, Ghana has held regular elections, which have been touted as free and fair by most observers. Additionally, elections have been highly competitive at least since 2000, mainly due to the solidified two-party system that has already led to multiple transfers of power through the ballot box, thus underlining Ghana's standing as a stable semi-democratic country. As has been argued by Whitfield (2009), the two-party system is a direct result of Ghana's decolonization process, which pinned two political traditions against each other: The Danquah/Busia and the Nkrumahist traditions.

The former refers to J. B. Danquah, who jump-started the struggle for independence, and K.A. Busia, Ghana's Prime Minister from 1969 to 1972. At its inception, the Danquah/Busia tradition set out to represent the new educated elite, consisting of lawyers and other mostly foreign-educated academics with Akan background. Their political style is popularly described as elitist, more liberal, and business-friendly, thus leaning towards the right-wing (Svanikier 2007, Whitfield 2009). The latter refers to the movement led by Kwame Nkrumah, Ghana's first president after independence. His political strategy can be described as a populist, people-centered, and more left-wing approach to politics, while also remaining ethnically more broad-based. 
While J. J. Rawlings came into power through a military coup in the late 1970s, he ultimately returned Ghana to democratic rule in 1992, establishing Ghana's current political system under the Fourth Republic. Although the two main parties of today were formally founded in 1992, both parties find their approach to politics within the aforementioned political traditions. In this respect, the NPP is the latest reincarnation of the Danquah/Busia tradition, following its described political style. Obeng-Odoom (2013) assigns the party to the philosophy of property-owning democracy. With a liberal approach to economic policy, the party's main aim is to attain macro-economic stability through prudent fiscal spending and low inflation and has therefore gained the reputation of being good economic and fiscal managers (Ninsin 2006). On the other hand, the NDC, which was founded by J. J. Rawlings to participate in the 1992 elections, cannot trace back its roots directly to the decolonization period, however, as argued by Whitfield (2009) and Jeffries and Thomas (1993), has been able to appropriate the Nkrumahist tradition for its own political benefit. As such, the NDC portrays itself as a non-elite movement and champion of the people, using a similar populist rhetoric (Whitfield 2009). Accordingly, the party sees itself committed to the social democratic philosophy, as proclaimed in its party constitution (Bob-Milliar 2012).

Ghana's political landscape is characterized by relatively stable voting patterns in past elections. Whereas the NPP has its traditional strongholds in the Ashanti and Eastern Regions, populated by the Akan tribes, the NDC mainly relies on strong support from the Volta Region, populated by the Ewe tribe. While these voting patterns suggest that party loyalties have ethnic roots, some scholars propose that party support has progressed to reflect other aspects of the respective political traditions (Whitfield 2009). Lindberg and Morrison (2008) attest to this, as they find that party considerations far outweigh individual considerations, such as the ethnicity of a candidate, in the parliamentary elections of 2008.

These aspects seem to suggest that Ghana's main political parties and their support base are characterized by meaningful ideological differentiation comparable to the situation in more mature Western democracies. Nevertheless, when analyzing both parties' track records during their terms in office, most scholars conclude that their policies are not predominately driven by ideology, but rather by other more pragmatic considerations (Ninsin 2006, BobMilliar 2012, Obeng-Odoom 2013). Despite his progressively leftist rhetoric, it was J. J. Rawlings who authored Ghana's shift towards a neo-liberal state in 1983 undergoing a promarket economic recovery program. The NDC's economic policy has since not broken with this stance, even after Rawlings' retirement. On the other hand, during its two terms in power between 2000 and 2008, the NPP put forward large government-sponsored programs to establish a welfare system and in 2016 mainly ran on its promise for free secondary education, arguably not a decidedly neo-liberal policy. Obeng-Odoom's (2013) profound analysis of the parties' manifestos before the 2012 election comes to the conclusion that both parties exert a common neo-liberal policy platform, with the NDC considerably deviating from its proclaimed social-democratic core. This lack of a distinguishable ideology also 
reflects in Van Gyampo's findings (2012), who shows that the vast majority of party supporters are unfamiliar with or disregard their party's ideology, even those with higher education.

Thus, while Ghana seems to be a consolidated electoral democracy, its party landscape and political competition are not inherently motivated by sophisticated political ideologies, neither on the supply nor on the demand side. This ultimately raises the question if strong partisan identities can form in such an environment.

\section{Study Design}

\subsection{Data}

The main data source of this paper consists of the surveys provided by the Afrobarometer project, which has been collecting public opinions on a wide range of governance issues in Africa. Ghana has been covered in all rounds, creating an extensive sample from 2002 to 2017 to analyze partisan identities over time and across different parts of the population. Afrobarometer uses national probability samples based on random selection in order to create representativeness across all citizens of voting age in a given country. For rounds 2 through 4 the sample size amounts to 1200 respondents $^{2}$, while rounds 5, 6 and 7 include 2400 respondents. More details on the sampling technics and other information on the Afrobarometer surveys can be found in the survey manual available online (Afrobarometer 2014).

The variables employed here measure individual perceptions and attitudes of the survey respondents with respect to different political issues, their personal situation and democratic values. The first set of variables includes a performance assessment and respondent's satisfaction with government on different issues. Then respondent's trust towards different public institutions is considered. Next are perceptions of living conditions and the economic conditions in the country. This is followed by more political perceptions on corruption, crime and government treatment. Lastly, respondent's attitudes towards a range of important principles of a democratic society are included. For obvious reasons the analyses also include a standard set of available individual characteristics of the surveyed respondents that likely affect their opinions, namely an individual's gender and age, religion, living locality, level of education, employment status and their ethnic group. All variables - except for age - are based on a categorical measurement scale with varying numbers of categories, some of which are binary by nature. More details on the exact wording of the survey questions and the respective coding of answers can be obtained from Table A1 in the Appendix, while Table A2 contains simple descriptive statistics of the employed dependent variables.

${ }^{2}$ Round 3 only includes 1197 , as 3 respondents are missing 


\subsection{Empirical Strategy}

Considering that the Afrobarometer surveys constitute a repeated cross-section, the statistical inference in this paper will be based on a pooled OLS model with unit- and timefixed effects. The political turnovers following the elections in 2008 and 2016 will provide the necessary variation in the respondents' opinions. This means NPP partisans express their opinions from 2002 to 2008 and after 2016, with their preferred party holding political power, while doing the same between 2009 and 2016 under the impression of a NDC presidency. Naturally, for NDC partisans the opposite holds true. The analysis will thus try to identify the change of the different dependent variables for both partisan groups that will react to a loss and gain of power, respectively. Further steps to produce reliable estimates need to address the likely presence of heteroscedasticity and serial correlation, as has been acknowledged by Cameron and Miller (2015) and Bertrand et al. (2004), respectively. Clustering the data will help to mitigate both of these problems and in line with the recommendation of Cameron and Miller (p. 18, 2015), I cluster the data at the progressively higher level, which in this case is the regional level ${ }^{3}$.

A natural problem of every observational study is that the composition of the comparison groups is not constructed randomly, thus leading to the likely situation that both groups differ systematically concerning important features that also have a bearing on the outcome variables under study. In my specific case, it can be expected that NPP and NDC supporters differ systematically with respect to important characteristics that might also influence their opinions. For instance, NDC partisans tend to live more rural and exhibit on average a lower level of education. Including control variables make sure that differences in opinions are not driven by these systematic differences in characteristics. Besides the living locality and education, it is furthermore necessary to control for the individuals' gender and age, as they will likely affect the respondents' responses. Furthermore, I also control the respondents' employment status, as again NDC partisans tend to have less stable employment. Lastly, given the importance of ethnicity in politics in Ghana and more generally in Africa, there is a need to control for this in order to capture a partisan and not an ethnic divide.

Ultimately, I estimate the following equation:

$$
\begin{aligned}
\text { Depend }_{i t} & =c+N P P_{-} \text {partisan }_{i}+\beta *\left(N P P \_ \text {partisan }_{i} * \text { time }_{t}\right) \\
& + \text { round }_{t}+\text { region }_{i}+X_{i t}+e_{i t}
\end{aligned}
$$

where the subscript $\boldsymbol{i}$ represents the different respondents and $\boldsymbol{t}$ the different time-periods in the sample. The dummy variable $\boldsymbol{N P P}_{\boldsymbol{p}} \boldsymbol{p a r t i s a n} i$ takes the value 1 for respondents that

\footnotetext{
${ }^{3}$ The presented results are robust to the clustering at different levels, such as districts and the primary sampling unit (PSU).
} 
are identified as NPP partisans and 0 for those that are NDC partisans, while the dummy variable time $_{\boldsymbol{t}}$ takes the value 1 for observations from survey rounds 5 and 6 , when the NDC held power, and 0 otherwise. These two dummy variables are then interacted producing an estimator for NPP partisans conditioned on the NDC holding power, with the coefficient $B$ marking the main coefficient of interest, as it estimates the average change in opinions of NPP partisans relative to NDC partisans when their party is in opposition. While $\boldsymbol{X}_{\boldsymbol{i t}}$ comprises the individual-level controls discussed above, round and region dummies are included to further control for unobserved factors specific to these units, and, finally, $\boldsymbol{e}_{i t}$ is the standard error term.

\section{Analysis and Results}

\subsection{Descriptive Analysis}

The descriptive statistics in Table 3 give a first indication that the opinions of party supporters are influenced by the political situations, as the performance and satisfactions variables are generally on average higher for both partisan groups when their preferred party is in power. While NPP partisans rate the performance of a NPP president on average with 3.4 , their rating for a NDC president is only 1.7. On the other hand, NDC partisans assess the performance of a NPP president with 2.4 on average, while their assessment of a NDC president is 3.0. This pattern also extends to the different measures on trust and the perceived living and economic conditions. Furthermore, the corruption perceptions indicate that only $14 \%$ of NPP partisans perceive most or all of the members of the president's office to be corrupt during a NPP presidency, while this figure rises to $52 \%$ during a NDC presidency. The same split for NDC partisans is $27 \%$ to $31 \%$. In general, one can observe that these gaps are larger for NPP partisans than for NDC partisans.

Considering that this simple comparison of averages is oblivious of general time trends, I will turn towards graphical depictions of the examined perceptions and attitudes across the different surveys. In this regard, figure 1 in the appendix illustrates the patterns of variables for both partisan groups across time in the form of margin plots with the horizontal bars indicating the two power shifts during the period of study. If the investigated opinions would be entirely unaffected by partisan motives, we would not necessarily expect them to be identical, but to follow a parallel trend in both groups. On the other hand, in case of strong partisan motives, we would expect the opinions in both partisan groups to alternate in line with the power shifts.

Figures 1.1 to 1.7 deal with the set of performance measures, which reveal a clear partisan divide on these measures that are strongly driven by the political situation in the country. The first figure indicates that in the surveys of period 1, during which the NPP held power, 
NPP partisan assessed the performance of the president significantly better than did NDC partisans, as demonstrated by the provided $95 \%$ confidence intervals. During period 2 , which is marked by the NDC holding power, the performance assessment in both partisan groups is reversed, as now NDC partisans assess 'their' president more favorably, while the assessment of NPP partisans plummets. In the last survey, conducted shortly after the NPP regained power, this pattern is once again turned on its head. The following figures display the same partisan pattern for a set of measures assessing the government's performance in different policy fields, i.e. the economy, providing jobs, education, health care, fighting crime and corruption. Here again NPP partisans provide much more favorable assessments, during times of NPP governments and much worse when the NDC holds power, with the assessments of NDC partisans following an opposite pattern. This presence of a partisan divide on performance assessments is not entirely surprising, as we would already expect it even with weak partisan identities.

Figures 1.8 to 1.13 illustrate the same margin plots for respondents' trust in different political and public institutions. The figures again indicate a clear partisan pattern regarding the trust of the president, parliament and both the ruling and opposition party. A partisan divide on these measures is again not so surprising given their political nature and their replacement along party lines following power shifts. However, figures 1.12 and 1.13 now assess the levels of trust towards the police and courts, both public institutions whose structure and behavior should not change significantly along party lines. Still, while the partisan divides are not always significantly different across all periods, a similar partisan pattern can be observed. Such patterns are not consistent with weak partisan identities.

The following figures examine different political and non-political perceptions. To begin with, figures 1.14 and 1.15 depict the respondents' perceived living conditions, first in absolute terms and then relative to other Ghanaians. And once again both measures appear to be driven by partisan-motivated reasoning, as both partisan groups are much more positive about their personal living conditions, when their preferred party is in power. Next, figures 1.16 and 1.17 display how both partisan groups perceive the present and future economic conditions in the country. In both cases the same partisan patterns emerge, while the partisan divide is decidedly smaller for the economic conditions of the future, which might partially be explained by the generally more favorable perceptions about the future. Figures 1.18 to 1.21 take a look at corruption perceptions. Again, there are partisan patterns, in particular for corruption involving the president and the members of parliament, but also with regard to the polices and judges, albeit without differing significance in all periods. Furthermore, the partisan divide in all four cases is considerably larger in 2014, due to a particular steep rise of corruption perceptions for NPP partisans. It appears the corruption scandals and their wide media coverage during the Mahama administration appear to have had a stronger influence on NPP partisans, again providing evidence for the presence of a partisan screening effect. Figure 1.22 analyzes respondents' perceived fear of crime and while 
the partisan gaps are not significantly different anymore, one can still observe the same shifts following the political turnovers after the 2008 and 2016 elections. As a last perception measure, figure 1.23 shows how respondents perceive being treated by the government. Once more one can observe partisan patterns, with NDC partisans feeling treated more unfairly than NPP partisans by the NPP government in the early study periods, while this gaps turns around after 2009 and again in 2017. Considering that the underlying question of this measure asks of unfair government treatment towards the respondents' ethnic group, this analysis suggests that partisanship also has an ethnic dimension.

Now turning to the analysis of political attitudes towards important democratic principles, figure 1.24 starts out with an analysis of attitudes towards the freedom of association, as respondents are asked of their opinion on the governments' authority to ban organizations that go against their policies. The plot reveals a partisan divide that shifts in line the power shifts, although the gap seems to grow smaller over time and ceases to be statistically significant. This pattern conveys a problematic message, partisans appear to be less demanding of their government to follow democratic principles, when their preferred party is in power. Next, figure 1.25 employs the freedom of press, another important pillar of a consolidated democracy, as dependent variable. In contrast to the previous figures, differences in attitudes towards a free press in both groups appear to be unaffected by the power shifts, as the linear predictions are remarkably parallel and not significantly different across the different surveys. While on average partisans appear to be more in favor of the government closing down newspapers during the NDC's time in power, this trend is broken up by rising sentiments in favor of a free press in the last survey, when the NPP had taken back power. Nevertheless, the principle of a free press appears to be valued by both partisan groups equally, independent of the political situation.

Figure 1.26 displays respondents' attitudes towards the multi-party system. Here the familiar partisan pattern can again be observed, as NDC partisans are more approving of having multiple parties than NPP partisans when their favored party is in opposition. This relationship is turned on its head, after the NDC took power in 2009 and switches back again after the renewed power shift after the 2016 elections. However, these differences in each year fail to be statistically significant. Still, the observed pattern suggests that partisans are much less demanding of this democratic principle when their favored party is in power indicating a hypocritical attitude towards democracy. Figure 1.27 provides additional evidence in this direction, plotting attitudes towards one-man rule, although the partisan pattern is not as clear cut, as in the previous figure.

Finally, figure 1.28 examines the partisans' attitudes towards elections as the tool to determine political leaders. Similar to the freedom of press, this attitude appears unaffected by partisan motives, as the trends in both groups are remarkably parallel, notwithstanding any power shifts. This result is indicative of the high standing of democratic elections in the Ghanaian population, irrespective of their partisan motivation. 
In concluding this section, a more general observation throughout this graphical analysis is that the responses of NPP partisans portray considerably stronger partisan patterns, as their opinions are much more volatile than those of NDC partisans. This could be suggestive of differences in the strength of party attachments, but also, as I will revisit later, could be the result of bias in the sample selection.

\subsection{Regression Analysis}

Table B1 provides the first set of results for the estimation of the empirical model described above, employing the different measures of government performance and satisfaction. The estimates of the partisan divide dummy are highly significant, while its negative signs indicate that NPP supporters assess government performance more negative relatively to NDC supporters, when the NDC is in power. This finding is indicative of the presence of partisan-motivated reasoning, while these differences in performance assessments are in line with the hypotheses formulated above and can be expected even with weaker partisan identities. Whereas the magnitude of the coefficient is considerably larger for the performance assessment of the president, the coefficients of the satisfaction measures are fairly similar across the different matters. This indicates that partisan motives are not tied to certain political issues, but provides some evidence for the steadfastness of partisan identities. The coefficient of the NPP partisan dummy has about half the size of the overall partisan divide dummy, which suggests that the partisan gaps are roughly symmetrical when either party is in power. The results also show that in contrast to the partisan motives the included individual-level controls appear to play a much smaller role in explaining the individuals' responses, given their general insignificance.

In the next step I expand the analysis to measures of trust. Table B2 collects the respective results. Columns (1) and (2) indicate a significant partisan divide on the trust of the president and the parliament, while the former effect is roughly double in size, suggesting stronger partisan-motivated reasoning. This is hardly surprising, considering the centrality of the president and that even when one party holds executive power, parliament still contains a considerable amount of representatives from the other party. Columns (3) and (4) look at respondents' trust towards the ruling and opposition party and again the results imply the presence of partisan identities. However, the partisan divide on the latter is much smaller than on the ruling party. This can mainly be attributed to the stronger reaction of NPP partisans following the power shifts on the ruling party measure compared to the opposition party measure, as can be observed in the margin plots (figures 1.10 and 1.11). It suggests that NPP partisans are much more enthusiastic about their own party, when they are in power, then they are averse to the NDC at the same time, while they are much more objecting towards the NDC, when they are in power, then they are in favor of their own party. This could be suggestive of an asymmetric partisan screening effect among NPP partisans. While the presence of a partisan divide on the previous measures is still not extremely surprising, 
given their political nature, columns (5) and (6) now report the results on trust towards the police and courts, both public institutions that are not immediately connected to a party. Nevertheless, the results still suggest a partisan divide, as NPP partisans have lower levels of trust towards both the police and the courts when their party is in opposition. Considering that there is neither a large replacement of policemen and-women, nor of judges following a power shift, this partisan divide suggests the presence of much stronger partisan identities. To further examine the pervasiveness of partisanship, I investigate additional non-political perceptions of the respondents in table B3. Columns (1) and (2) report the perceived personal living conditions of partisans, once in absolute terms and also relatively to other Ghanaians. The results again indicate a partisan pattern, as both NPP and NDC partisans appear to perceive their personal living conditions as significantly better, when their favored party is in power. Around the political turnovers in the sample one can observe marked changes in these perceptions. The analysis continues in columns (3) and (4) with perceptions of economic conditions in the country, first at present, and then looking into the future. Both measures are subject to a considerable partisan divide, as NPP supporters' assessment of the economy drops considerably when their party is not in power, which is very much in line with the results on the perceived living conditions.

Table B4 continues with further perception measures, employing the respondents' corruption perceptions of the president, members of parliament, the police force and judges in columns (1) to (4), respectively. Once again, a significant partisan divide between both groups emerges for all measures, suggesting that NPP partisans perceive the country to be more corrupt when the NDC holds power at the national level. This partisan pattern on perceived corruption of the police force and judges again suggests elevated levels of partisan identities. Extending the analysis further, column (5) reports results for perceptions of personal security. Here again, a significant partisan divide can be observed, as both partisan groups are more fearful of being the victim of a crime when their party is not in power. This finding matches the partisan divide on government satisfaction in fighting crime and also suggests that partisans are consistent in applying their motivated reasoning, further substantiating the meaningfulness of partisan identities. Lastly, column (6) displays partisans' perceptions on government treatment of their own ethnic group, showing a partisan pattern which implies that partisanship also has an ethnic dimension. This is hardly surprising given the ethnic background of both parties described in section 2 .

In summary, the analysis uncovers a partisan divide that runs like a common thread through the analysis of all examined opinions and perceptions, indicating a persistent presence of motivated reasoning which provides evidence for stable and meaningful partisan identities.

Considering Africa's volatile history with democracy, understandingly there has been great interest in the consolidation process of democratic institutions and principles. Partisan 
identities will likely also play a role in this process that needs to be investigated. Therefore, I analyze the presence of partisan motives in attitudes towards important democratic principles. Table B5 depicts the respective results with columns (1) and (2) using respondents' attitudes towards important democratic principles, namely the freedom of association and a free press. Results on the former once more indicate a profound partisan divide, as both partisan groups are more insistent on their right to associate freely when their party is in opposition than when it holds power. On the other hand, the attitudes towards a free press seem unaffected by partisan motives, as the different party supporters seem equally in favor of a free press independent of their own party currently holding political power or not.

Columns (3) and (4) shed more light on how deeply rooted the democratic system is in partisan citizens by investigating their attitudes towards one-party and one-man-rule. The result shows that there appear to be partisan effects at play, as partisans are less approving of the democratic system when their party is in power. It would seem reasonable for partisan supporters to be more in favor of a political system when this system has put their party in power. However, empirical evidence rather suggests the opposite, as partisans seem to be more in favor of curtailing democratic institutions potentially in the hopes of consolidating the status quo with their preferred party in power. Finally, column (5) looks at attitudes towards democratic elections in general. There appears to be no evidence that these attitudes are affected by the power shifts, indicating that they are not subject to motivated reasoning.

While the lack of partisan motives regarding the attitudes towards a free press and democratic elections are encouraging, the partisan patterns on the other democratic principles are more disconcerting. It appears that some democratic principles do not receive unconditional support among partisan citizens. The evidence suggests a worrying double standard, as partisans seem to appreciate and demand more democracy, when their preferred party is in opposition, potentially protecting them from discrimination by their political rivals. However, when their party is in power, they seem much more indifferent on these democratic protections, as less democratic restrictions might benefit them in this situation.

\subsection{Robustness Tests}

Obviously, the above analysis is subject to concerns regarding the appropriate identification of the claimed effects and possible alternative explanations. Here I want to address some of these concerns in order to validate the result's interpretation and robustness.

To begin with, some of the reported changes in perceptions could be the result of actual changes and will likely be informed by varying experiences between the respondents. Considering the well-established concept of pork-barrel politics, there is an extensive literature on distributive politics within the African context, with early contributions like Morrison and Stevenson (1972) and Bates (1974) to more recent contributions that describe compelling evidence of political favoritism (Hodler and Raschky 2014, Burgess et al. 2015, 
Kramon and Posner 2016, Dickens 2018). Consequently, it appears plausible that the government uses its political power to funnel public resources towards their supporters, which could then explain the large difference in perceived living conditions between both groups. Investigating this possibility, I analyze the changes in the access to public utilities and the ownership of certain assets to control for political favoritism. Columns (1) and (2) of table $\mathrm{B} 6$ depict the results of the respective analysis, indicating that there appears to be no evidence of any significant changes in the access to public utilities depending on either party being in power. ${ }^{4}$ The same appears to be the case when employing an index of asset ownership, as there are no significant changes associated with the political turnovers.

Likewise, the observed changes in perceived corruption could also be the result of simultaneous changes in experience with corruption. To test this hypothesis, I use respondents' experience with bribing the police or public officials to get a document or permit. The results are collected in columns (3) and (4) and indicate that there appears to be no shift in the experience of paying bribes dependent on which party is in power. The patterns of corruption perceptions can therefore not be explained by actual changes in the experience with bribery.

Lastly, the fear of being the victim of a crime could of course be affected by actually having direct experience with a crime. To control for this, I run the baseline regression using a measure on how often respondents or anyone in their family have been physically attacked in the year before the respective survey. The results in column (5) again show no significant difference between both partisan groups that would be able to explain the observed partisan pattern on the fear of crime. At least with the available measures used here, actual changes and experiences cannot serve as an explanation for the patterns of perceived living conditions, corruption perceptions and the fear of crime reported above. It rather seems that these perceptions are to a large extent driven by partisan identities and the associated motivated reasoning.

Another concern is that of simultaneity, meaning that it could be the respondents' opinions that determine their choice of partisanship and not the other way around. This is particularly relevant for performance assessments, as respondents might have a positive assessment of the current government and therefore identify as a supporter of the ruling party, making both issues sticky and hard to disentangle. However, for reverse causality to be the case there would need to be an explanation for the strong differences in both groups in the first place (Carlson 2016). This direction of causation would also be more in line with the "running tally" model of partisanship, which has generally fallen out of favor, following more credible evidence pointing towards partisanship having a more causal role in shaping political perceptions and attitudes (Bartels 2002). And even if the results would be a result of reverse

\footnotetext{
4 This access is measured by a public utility index that combines the access to electricity, piped water, schools, and health clinics in the respondents' neighborhoods, as reported by the survey interviewer. All measures of the index can also be tested separately, without producing any evidence for political favoritism.
} 
causality, it would still indicate that partisanship in Africa is meaningful in that people feel obliged to align their political opinions and their proclaimed partisanship. While I am not able to categorically reject the possibility of reverse causality in my setting, based on the mentioned arguments I identify pre-existing partisan identities as the more likely source of the observed changes political perceptions and attitudes.

The sample selection is another relevant concern, which could be a problem for inference. As respondents self-declare their partisan affiliation there is the possibility for bias due to strategic responses, meaning respondents hide their true affiliation or even misreport it. A closer look at the employed sample lends further support for the presence of such strategic responses. In the surveys taken during a NPP presidency, 69 percent in the sample report an affiliation with the NPP, while only 31 percent identify as NDC supporters. In contrast, with the NDC holding power at the national level, NPP partisans make up only 46 percent of the sample, with 54 percent indicating support for the NDC. 5 This observation suggests that some respondents feel the need to hide their true party affiliation when their party is in opposition, potentially out of fear of harassment by the government. Considering that more than half of the respondents in the sample believe that the Afrobarometer surveys are conducted by the government or a related entity this is hardly surprising. In this regard, NDC partisan seem to be slightly more suspicious than their NPP counterparts.

Exploiting the stable voting patterns in Ghana might help to give some insight into this phenomenon. For this, I define party strongholds as those constituencies where either party receives more than 70 percent of the presidential vote. Accordingly, in NPP strongholds, where on average about 80 percent voted for the NPP independent of which party was in power, 56 percent of the respondents in my sample identified as NPP partisans during an NPP presidency, while the same holds true for 47 percent during an NDC presidency. On the other hand, in NDC strongholds, where the NDC candidate receives on average about 84 percent of the presidential vote in either time period, only about 44 percent of respondents identify as NDC supporters while their party was in power and 35 percent during a NPP presidency. These numbers seem to suggest that the misreporting of party allegiance is more widespread among NDC supporters. While it is not immediately clear if it is rather stronger or weaker supporters that misreport their affiliation, one might assume the former to be the case, as stronger partisans might be more fearful of discrimination against them. Under this assumption the provided estimates for the partisan divide would represent lower bounds and given the suggestive evidence that misreporting is more widespread among NDC supporters, would be able to explain the more muted response pattern for NDC partisans observed in the graphical analysis.

\footnotetext{
${ }^{5}$ Here it needs to be stressed that partisanship is not measured by vote choice. While vote choice can be expected to vary significantly following a political turnover, as it also includes swing voters, such a notable change in the composition of the sample, can most likely only be explained by the presence of strategic responses.
} 
Accordingly, as an alternative I propose a different strategy to sample partisans based on geographical identification to verify the robustness of the results. According to this strategy, respondents are assigned to either partisan group if they are located in an electoral stronghold of the respective party. Strongholds are again defined by a vote share of more than 70 percent for the respective party in the closest presidential election. NPP partisans will thus be identified by living in a constituency, where the vote share of the NPP presidential candidate exceeded 70 percent in the corresponding national election. Likewise, respondents will be identified as NDC partisans, when they are living in a constituency where the vote share of the NDC candidate exceeded 70 percent. To establish respondents' connection to their constituencies, I make use of the provided geocodes in the Afrobarometer samples. This strategy will most likely underestimate partisan gaps, as party strongholds for either party naturally also include non-partisans and stated partisans of the other party. And indeed my sample shows that in NPP strongholds about 42 percent of respondents do not affiliate with either party and 6 percent support the NDC. Similarly, in NDC strongholds, 43 percent of respondents identify as independents, while 18 percent state an affiliation with the NPP. The respective results of this analysis are collected in tables B7 and B8. The results do not differ from those of the baseline regressions, both in terms of statistical significance and generally also the magnitude of the effects. While this strategy might also have its flaws, considering that it largely leads to the same results provides some confidence in the validity of the baseline results.

A final concern would be the presence of other unaccounted aspects that might affect the analyzed perceptions and attitudes and the possibility that the political turnovers itself are determined by the changes of the respondents' opinions. Considering that the employed sample includes multiple points of time before and after the turnover, it is possible to conduct an analysis of trends before the political turnovers. Examining the margin plots in figure panel 1 indicate that the trends for both partisan groups appear to be remarkably parallel across the three survey rounds before the first turnover in 2009 and even between the surveys in 2012 and 2014, trends seem to be largely parallel. The only exception appears to be the measures on corruption perceptions that display a much steeper increase between 2012 and 2014 among NPP partisans. However, this observation is actually quite compatible with the presence of partisan motivation, as it suggests that the increased media coverage of possible corrupt practices during the Mahama regime in 2014 left a greater impression on NPP partisans than on NDC partisans, thus explaining the divergence of their perceptions. Nevertheless, the generally parallel trends between turnovers suggest that other aspect only seem to play a minor role. 


\subsection{Partisan Identities and Ethnicity}

As the final step of the analysis, I investigate the role of ethnicity in partisan identities. As has been stressed before ethnicity plays an important role in virtually all African societies and hence also has a great influence on politics in Africa. Given its political history outlined above, Ghana is no exception to this observation, although some scholars have been pointing towards a fading of the ethnic dimension in Ghana's party landscape. To investigate how ethnicity affects the observed partisan divide, I combine the two main ethnic groups that are connected to either party in a dummy, i.e. the Akan people for the NPP and the Ewe people for the NDC. This dummy is then interacted with the partisan divide dummy to test if partisans belonging to these two ethnic groups are farer apart in their opinions or not. The respective results are reported in tables B9 and B10.

A first result of this analysis is that the coefficients on the partisan divide dummy continues to be statistically significant across most of the dependent variables. This again supports the finding that the divide in opinions between both groups is not solely an ethnic divide, but rather based on partisan affiliation as such, given that partisans from the other ethnic groups also exhibit significant differences in their opinions in connection with the political turnovers. Secondly, the coefficient of the added interaction term is highly significant in the majority of specifications and also of the same sign than the partisan divide coefficient. This indicates that the partisan divide between NPP and NDC supporters is more pronounced when they belong to the Akan or Ewe ethnicity. The measures of perceived corruption appear to be an exception, as here the partisan divide is not significantly moderated by the ethnic affiliation of the respondents. Furthermore, it seems that the partisan patterns on the political attitudes are mainly driven by ethnicity. In line with Carlson (2016), these results suggest that partisan identity exists separately from ethnic identity, but ethnicity still is a strong predictor of the strength of party attachment in Ghana.

\section{Conclusion}

Exploring changes in opinions of partisan citizens in conjunction with political turnovers, this study provides evidence for the presence of strong and stable patterns of partisanship in African voters. In line with theories on motivated reasoning, the opinions and assessments of partisan citizens seem to be affected by their pre-dispositions, resulting in the well-known partisan screening effect. Considering that these partisan patterns can be observed consistently across many different measures of performance evaluations, trust, political and non-political perceptions and attitudes, suggests that they are part of an elaborate partisan identity. Further tests show that these partisan identities are not merely based on ethnicity, a long held belief in the literature, specifically in Sub-Saharan Africa.

Naturally, these findings come with certain implications. First, they imply that such stable partisan identities can evolve in new democratic systems, even if parties are young and do 
not have sophisticated ideologies behind them. On the one hand, this means that researchers cannot continue to ignore the importance of partisanship, when studying the economic and political behavior of ordinary citizens in Africa. On the other hand, this also reveals the need to update the prevailing theories on the origins of partisanship. In this regard, the results point towards a substantial polarization among citizens, given what we know from social identity literature (Chen and Li 2009, Kranton et al. 2013), this could serve as an important explanation for how partisan identities have evolved in the Ghanaian context, pinning the supporters of the two main parties against each other. On the other hand, this partisan polarization can also be seen as a threat to the political and social order. Furthermore, the results suggest that the process of evaluating political parties and candidates - which is naturally very important in a democracy - could in large parts be driven by partisan predispositions and less by actual performance. This is clearly problematic for the effectiveness of democratic accountability, and could provide an explanation for the puzzle of why voters ever so often fail to punish poorly performing leaders at the ballot boxes. Further, considering that partisan motives also seem to affect the attitudes towards some important democratic values, partisan polarization could constitute a considerable impediment to the consolidation of democracy.

In any case, further research is necessary to fully understand the conditions behind the development of partisan motives in young democracies, specifically in the African context. Another focus of future research could be to investigate how partisanship affects the deepening of democratic institutions and the political discourse. In this regard, one could focus on other issues besides ethnicity that potentially moderate partisanship, in particular the provision of information through the media and more importantly alternative news sources that have gained importance with the spread of mobile devices and the internet, also in Africa. 


\section{Appendix}

\section{Table A1. Definition of Variables}

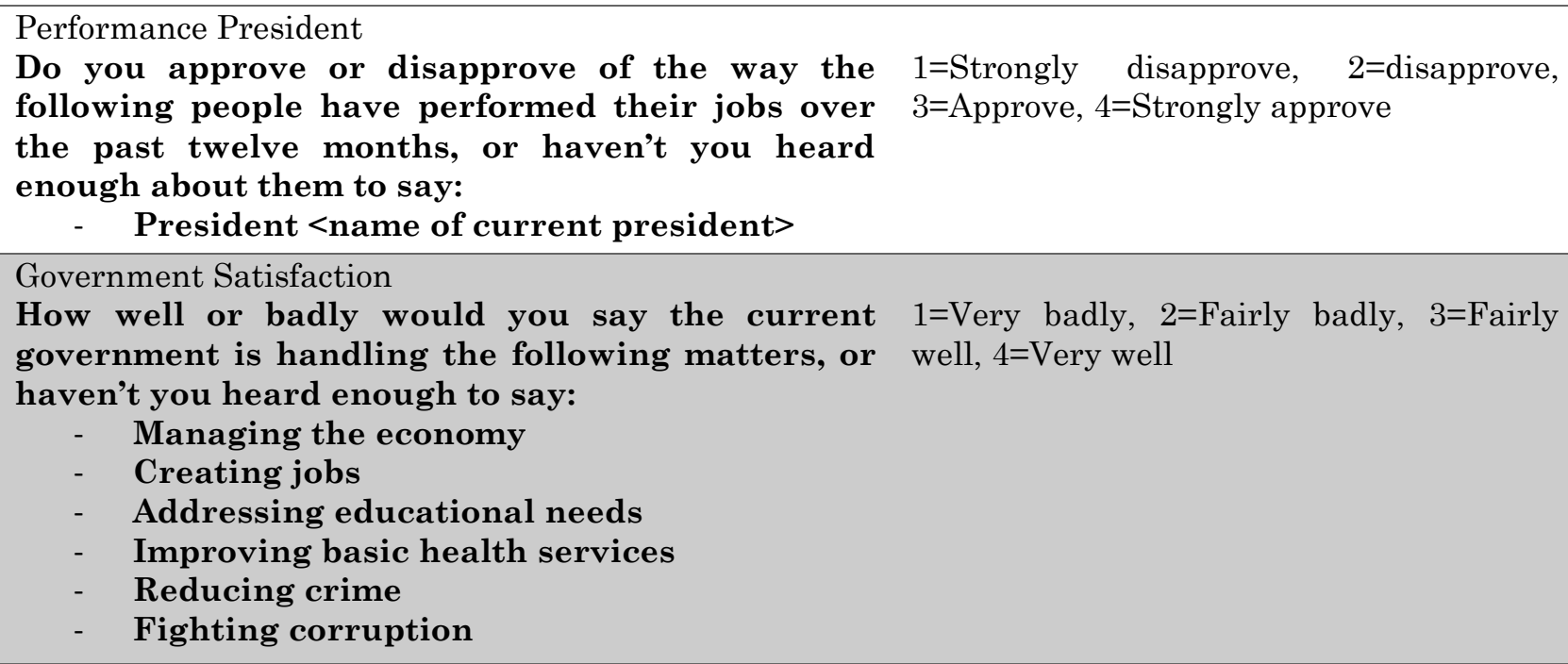

Trust

How much do you trust each of the following, or $0=$ Not at all, $1=$ Just a little, $2=$ Somewhat, haven't you heard enough about them to say: $\quad 3=\mathrm{A}$ lot

- The President

- Parliament

- The Ruling Party

- Opposition Political Parties

- The Police

- Courts of law

Living Conditions

In general, how would you describe:

- Your own present living conditions

1=Very Bad, 2=Fairly Bad, 3=Neither Good

- Your living conditions compared to those of nor Bad, 4=Fairly Good, 5=Very Good other Ghanaians

Economic Conditions (present)

In general, how would you describe:

The present economic condition of this Good nor Bad, 4=Fairly Good, 5=Very country?

Good

Economic Conditions (future)

Looking ahead, do you expect the following to be $1=$ Much worse, $2=$ Worse, $3=$ Same, better or worse

- Economic conditions in this country in twelve months time

Corruption Perceptions

How many of the following people do you think are involved in corruption, or haven't you heard

$0=$ None/Some of them, $1=$ Most or All of enough about them to say:

- President

- Members of Parliament

- Police

- Judges 
Security

Over the past year, how often, if ever, have you or anyone in your family:

$0=$ Never, $1=$ Just once or twice, $2=$ Several times, $3=$ Many times, $4=$ always

- Feared crime in your own home

Unfair Government Treatment

How often, if ever, are s [R's Ethnic Group] treated unfairly by the government?

$0=$ Never,$\quad 1=$ Sometimes, $\quad 2=$ Often,

\begin{abstract}
Democratic Principles \#1
Which of the following statements is closest to your view? Choose Statement 1 or Statement 2:

- Freedom of Association:

- Statement 1: Government should be able to ban any organization that goes against its policies.

- Statement 2: We should be able to join any organization, whether or not the government approves of it.
\end{abstract}

- Freedom of Press:

- Statement 1: Government should be able to close newspapers that print stories it does not like.

- Statement 2: The news media should be free to publish any story that they see fit without fear of being shut down.

- Electoral Democracy:

- Statement 1: We should choose our leaders in this country through regular, open and honest elections.

- Statement 2: Since elections sometimes produce bad results, we should adopt other methods for choosing this country's leaders.

Democratic Principles \#2

There are many ways to govern a country. Would you disapprove or approve of the following alternatives:

- Only one political party is allowed to stand for election and hold office?

- Elections and Parliament are abolished so that the President can decide everything?

\section{Utilities}

Are the following services/facilities present in the primary sampling unit/enumeration area:

- Electricity grid

- Piped water system

- School

- Health Clinic
$1=$ Strongly disapprove, 2=Disapprove, $3=$ Neither approve nor disapprove, $4=$ Approve, $5=$ Strongly approve

$0=$ None, $1=$ at least one of them, $2=$ at least two of them, $3=$ at least three of them, $4=$ all four of them 


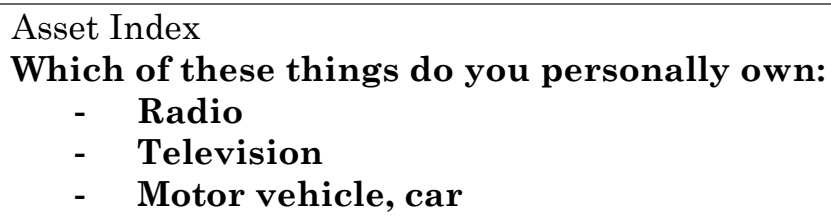

Attacked

Over the past year, how often (if ever) have you or anyone in your family:

- Been physically attacked

\begin{tabular}{|c|c|}
\hline Gender & $0=$ Female, $1=$ Male \\
\hline $\begin{array}{l}\text { Location } \\
\text { Is the PSU urban or rural? }\end{array}$ & $0=$ Rural, $1=$ Urban \\
\hline $\begin{array}{l}\text { Education } \\
\text { What is the highest level of education you have } \\
\text { completed? }\end{array}$ & $\begin{array}{l}0=\text { No formal or informal schooling only, } \\
1=\text { Some primary or primary completed, } \\
2=\text { Some secondary or secondary completed, } \\
3=\text { Post-secondary qualifications or higher }\end{array}$ \\
\hline
\end{tabular}

Employment

Do you have a job that pays a cash income? Is it full- $0=$ No (Not looking), $1=$ No (Looking), $2=$ Yes, time or part-time? And are you presently looking part-time (looking and not looking), $3=Y e s$, for a job (even if you are presently working)? full-time (looking and not looking)

\begin{tabular}{ll}
\hline Age & A numeric value between 18 and 110 \\
\hline $\begin{array}{l}\text { Religion } \\
\text { What is your religion, if any? }\end{array}$ & $0=$ Christian, $1=$ Muslim, $2=$ Other \\
\hline $\begin{array}{l}\text { Ethnicity } \\
\text { Which Ghanaian language is your home language? }\end{array}$ & $1=$ Akan, $2=$ Ewe, $3=\mathrm{Ga}, 4=$ Northern
\end{tabular}


Table A2. Descriptive Statistics of main Dependent Variables

\begin{tabular}{|c|c|c|c|c|c|c|c|c|}
\hline \multirow{2}{*}{ Variables } & \multicolumn{4}{|c|}{ Full Sample } & \multicolumn{2}{|c|}{ NPP Partisans } & \multicolumn{2}{|c|}{ NDC Partisans } \\
\hline & Mean & SD & Min & Max & Mean (NPP Pres) & Mean (NDC Pres) & Mean (NPP Pres) & Mean (NDC Pres) \\
\hline $\begin{array}{l}\text { Performance } \\
\text { President }\end{array}$ & $\begin{array}{l}2.798 \\
(5778 \mathrm{obs})\end{array}$ & 1.065 & 1 & 4 & 3.449 (2296 obs) & 1.737 (1340 obs) & 2.417 (1010 obs) & 3.075 (1132 obs) \\
\hline $\begin{array}{l}\text { Government Satis. } \\
\text { (Economy) }\end{array}$ & $\begin{array}{l}2.476 \\
(5749 \text { obs) }\end{array}$ & 1.024 & 1 & 4 & 3.083 (2265 obs) & 1.587 (1340 obs) & 2.169 (1004 obs) & $2.582(1140 \mathrm{obs})$ \\
\hline $\begin{array}{l}\text { Government Satis. } \\
\text { (Jobs) }\end{array}$ & $\begin{array}{l}2.190 \\
(5716 \mathrm{obs})\end{array}$ & 0.990 & 1 & 4 & 2.667 (2232 obs) & 1.496 (1334 obs) & 1.893 (1009 obs) & $2.332(1141 \mathrm{obs})$ \\
\hline $\begin{array}{l}\text { Government Satis. } \\
\text { (Education) }\end{array}$ & $\begin{array}{l}2.737 \\
(5836 \mathrm{obs})\end{array}$ & 1.010 & 1 & 4 & 3.227 (2302 obs) & 1.941 (1342 obs) & 2.627 (1048 obs) & 2.783 (1144 obs) \\
\hline $\begin{array}{l}\text { Government Satis. } \\
\text { (Health) }\end{array}$ & $\begin{array}{l}2.648 \\
(5775 \mathrm{obs})\end{array}$ & 0.972 & 1 & 4 & 3.043 (2264 obs) & 1.960 (1340 obs) & 2.497 (1026 obs) & 2.807 (1145 obs) \\
\hline $\begin{array}{l}\text { Government Satis. } \\
\text { (Crime) }\end{array}$ & $\begin{array}{l}2.618 \\
(5746 \mathrm{obs})\end{array}$ & 1.017 & 1 & 4 & 3.018 (2266 obs) & 2.008 (1332 obs) & 2.275 (1008 obs) & 2.838 (1140 obs) \\
\hline $\begin{array}{l}\text { Government Satis. } \\
\text { (Corruption) }\end{array}$ & $\begin{array}{l}2.451 \\
(5561 \mathrm{obs})\end{array}$ & 1.051 & 1 & 4 & 3.009 (2175 obs) & 1.620 (1329 obs) & $2.249(941 \mathrm{obs})$ & $2.522(1116 \mathrm{obs})$ \\
\hline Trust (President) & $\begin{array}{l}1.894 \\
(5836 \mathrm{obs})\end{array}$ & 1.165 & 0 & 3 & $2.552(2317 \mathrm{obs})$ & 0.848 (1339 obs) & 1.459 (1030 obs) & 2.177 (1150 obs) \\
\hline $\begin{array}{l}\text { Trust } \\
\text { (Parliament) }\end{array}$ & $\begin{array}{l}1.646 \\
(5758 \mathrm{obs})\end{array}$ & 1.070 & 0 & 3 & $2.019(2268$ obs $)$ & $1.034(1335 \mathrm{obs})$ & $1.512(1015$ obs $)$ & 1.739 (1140 obs) \\
\hline $\begin{array}{l}\text { Trust (Ruling } \\
\text { Party) }\end{array}$ & $\begin{array}{l}1.706 \\
(5822 \text { obs })\end{array}$ & 1.158 & 0 & 3 & 2.327 (2303 obs) & 0.745 (1339 obs) & 1.214 (1034 obs) & 2.024 (1146 obs) \\
\hline $\begin{array}{l}\text { Trust (Opposition } \\
\text { Party) }\end{array}$ & $\begin{array}{l}1.480 \\
(5730 \mathrm{obs})\end{array}$ & 1.091 & 0 & 3 & 1.194 (2259 obs) & $1.829(1329$ obs $)$ & 1.763 (1016 obs) & $1.388(1126$ obs $)$ \\
\hline Trust (Police) & $\begin{array}{l}1.413 \\
(5851 \mathrm{obs})\end{array}$ & 1.139 & 0 & 3 & $1.628(2316 \mathrm{obs})$ & $1.072(1340 \mathrm{obs})$ & 1.327 (1042 obs) & 1.455 (1153 obs) \\
\hline Trust (Courts) & $\begin{array}{l}1.661 \\
(5747 \mathrm{obs})\end{array}$ & 1.075 & 0 & 3 & $1.782(2280 \mathrm{obs})$ & 1.325 (1327 obs) & 1.659 (1014 obs) & $1.813(1126$ obs $)$ \\
\hline $\begin{array}{l}\text { Living Conditions } \\
\text { (absolute) }\end{array}$ & $\begin{array}{l}2.404 \\
(5901 \mathrm{obs})\end{array}$ & 1.345 & 1 & 5 & 2.685 (2339 obs) & 1.947 (1343 obs) & 2.191 (1065 obs) & $2.564(1154 \mathrm{obs})$ \\
\hline
\end{tabular}


Table A2. Descriptive Statistics of main Dependent Variables, continued

\begin{tabular}{|c|c|c|c|c|c|c|c|c|}
\hline \multirow{2}{*}{ Variables } & \multicolumn{4}{|c|}{ Full Sample } & \multicolumn{2}{|c|}{ NPP Partisans } & \multicolumn{2}{|c|}{ NDC Partisans } \\
\hline & Mean & SD & Min & Max & Mean (NPP Pres) & Mean (NDC Pres) & Mean (NPP Pres) & Mean (NDC Pres) \\
\hline $\begin{array}{l}\text { Living Conditions } \\
\text { (relative) }\end{array}$ & $\begin{array}{l}2.921 \\
(5608 \mathrm{obs})\end{array}$ & 1.099 & 1 & 5 & 3.091 (2201 obs) & 2.695 (1283 obs) & 2.765 (1002 obs) & 2.983 (1122 obs) \\
\hline $\begin{array}{l}\text { Economic Cond. } \\
\text { (present) }\end{array}$ & $\begin{array}{l}2.348 \\
(5859 \mathrm{obs})\end{array}$ & 1.368 & 1 & 5 & 2.810 (2314 obs) & 1.625 (1345 obs) & 2.093 (1050 obs) & 2.496 (1150 obs) \\
\hline $\begin{array}{l}\text { Economic Cond. } \\
\text { (future) }\end{array}$ & $\begin{array}{l}3.628 \\
(5096 \text { obs })\end{array}$ & 1.240 & 1 & 5 & $3.973(2070$ obs $)$ & 3.066 (1160 obs) & 3.364 (850 obs) & 3.789 (1016 obs) \\
\hline $\begin{array}{l}\text { Corruption } \\
\text { (President) }\end{array}$ & $\begin{array}{l}0.285 \\
\text { (5929 obs) }\end{array}$ & 0.451 & 0 & 1 & 0.142 (2345 obs) & 0.525 (1351 obs) & 0.312 (1070 obs) & 0.270 (1163 obs) \\
\hline Corruption (MPs) & $\begin{array}{l}0.297 \\
(5929 \mathrm{obs})\end{array}$ & 0.457 & 0 & 1 & 0.178 (2345 obs) & 0.494 (1351 obs) & 0.291 (1070 obs) & 0.313 (1163 obs) \\
\hline $\begin{array}{l}\text { Corruption } \\
\text { (Police) }\end{array}$ & $\begin{array}{l}0.404 \\
\text { (5929 obs) }\end{array}$ & 0.491 & 0 & 1 & 0.365 (2345 obs) & 0.497 (1351 obs) & 0.409 (1070 obs) & 0.369 (1163 obs) \\
\hline $\begin{array}{l}\text { Corruption } \\
\text { (Judges) }\end{array}$ & $\begin{array}{l}0.339 \\
\text { (5929 obs) }\end{array}$ & 0.473 & 0 & 1 & $0.292(2345$ obs $)$ & 0.463 (1351 obs) & 0.336 (1070 obs) & 0.293 (1163 obs) \\
\hline Fear of Crime & $\begin{array}{l}0.482 \\
\text { (5913 obs) }\end{array}$ & 0.986 & 0 & 4 & 0.533 (2343 obs) & 0.386 (1349 obs) & 0.650 (1066 obs) & 0.337 (1155 obs) \\
\hline $\begin{array}{l}\text { Unfair Gov. } \\
\text { Treatment }\end{array}$ & $\begin{array}{l}0.647 \\
(5552 \text { obs })\end{array}$ & 0.948 & 0 & 3 & 0.475 (2198 obs) & 0.838 (1271 obs) & 0.901 (984 obs) & 0.541 (1099 obs) \\
\hline $\begin{array}{l}\text { Freedom of } \\
\text { Association }\end{array}$ & $\begin{array}{l}2.750 \\
(4989 \text { obs })\end{array}$ & 1.182 & 1 & 4 & $2.679(1730 \mathrm{obs})$ & 2.911 (1297 obs) & 2.833 (836 obs) & $2.614(1126$ obs $)$ \\
\hline Freedom of Press & $\begin{array}{l}2.555 \\
\text { (5022 obs) }\end{array}$ & 1.223 & 1 & 4 & 2.775 (1731 obs) & 2.207 (1316 obs) & 2.832 (834 obs) & 2.421 (1141 obs) \\
\hline One-Party Rule & $\begin{array}{l}1.734 \\
\text { (5867 obs) }\end{array}$ & 1.222 & 1 & 5 & 1.833 (2319 obs) & $1.516(1348 \mathrm{obs})$ & 1.706 (1046 obs) & $1.814(1154 \mathrm{obs})$ \\
\hline One-Man Rule & $\begin{array}{l}1.559 \\
\text { (5821 obs) }\end{array}$ & 0.994 & 1 & 5 & 1.577 (2292 obs) & 1.414 (1346 obs) & 1.590 (1037 obs) & 1.663 (1146 obs) \\
\hline $\begin{array}{l}\text { Electoral } \\
\text { Democracy }\end{array}$ & $\begin{array}{l}1.467 \\
\text { (5835 obs) }\end{array}$ & 0.836 & 1 & 4 & 1.479 (2303 obs) & $1.336(1342 \mathrm{obs})$ & 1.609 (1041 obs) & 1.466 (1149 obs) \\
\hline
\end{tabular}


Table B1. Baseline Regression: Performance and Government Satisfaction

\begin{tabular}{|c|c|c|c|c|c|c|c|}
\hline VARIABLES & $\begin{array}{c}(1) \\
\text { Performance } \\
\text { President }\end{array}$ & $\begin{array}{c}(2) \\
\text { Satisfaction } \\
\text { (Economy) }\end{array}$ & $\begin{array}{c}(3) \\
\text { Satisfaction } \\
\text { (Jobs) }\end{array}$ & $\begin{array}{c}\text { (4) } \\
\text { Satisfaction } \\
\text { (Education) }\end{array}$ & $\begin{array}{c}(5) \\
\text { Satisfaction } \\
\text { (Health) }\end{array}$ & $\begin{array}{c}(6) \\
\text { Satisfaction } \\
\text { (Crime) }\end{array}$ & $\begin{array}{c}(7) \\
\text { Satisfaction } \\
\text { (Corruption) }\end{array}$ \\
\hline NPP Partisan & $\begin{array}{c}1.031^{* * *} \\
(0.077)\end{array}$ & $\begin{array}{c}0.914^{* * *} \\
(0.062)\end{array}$ & $\begin{array}{c}0.755^{* * *} \\
(0.095)\end{array}$ & $\begin{array}{c}0.628^{* * * *} \\
(0.096)\end{array}$ & $\begin{array}{c}0.602^{* * *} \\
(0.083)\end{array}$ & $\begin{array}{c}0.723^{* * *} \\
(0.068)\end{array}$ & $\begin{array}{c}0.732^{* * * *} \\
(0.085)\end{array}$ \\
\hline $\begin{array}{l}\text { Partisan } \\
\text { Divide }\end{array}$ & $\begin{array}{c}-2.365^{* * * *} \\
(0.130)\end{array}$ & $\begin{array}{c}-1.899 * * * \\
(0.108)\end{array}$ & $\begin{array}{c}-1.603^{* * *} \\
(0.132)\end{array}$ & $\begin{array}{c}-1.499^{* * *} \\
(0.147)\end{array}$ & $\begin{array}{c}-1.425^{* * *} \\
(0.139)\end{array}$ & $\begin{array}{c}-1.578^{* * *} \\
(0.115)\end{array}$ & $\begin{array}{c}-1.660^{* * *} \\
(0.109)\end{array}$ \\
\hline Gender & $\begin{array}{l}-0.023 \\
(0.020)\end{array}$ & $\begin{array}{l}-0.054 \\
(0.038)\end{array}$ & $\begin{array}{c}0.008 \\
(0.035)\end{array}$ & $\begin{array}{c}0.002 \\
(0.028)\end{array}$ & $\begin{array}{c}0.000 \\
(0.031)\end{array}$ & $\begin{array}{l}-0.041 \\
(0.024)\end{array}$ & $\begin{array}{l}-0.000 \\
(0.015)\end{array}$ \\
\hline Location & $\begin{array}{c}0.032 \\
(0.028)\end{array}$ & $\begin{array}{l}-0.036^{*} \\
(0.018)\end{array}$ & $\begin{array}{c}0.024 \\
(0.021)\end{array}$ & $\begin{array}{l}-0.047 \\
(0.029)\end{array}$ & $\begin{array}{l}-0.022 \\
(0.028)\end{array}$ & $\begin{array}{l}-0.035 \\
(0.021)\end{array}$ & $\begin{array}{l}0.049^{*} \\
(0.023)\end{array}$ \\
\hline Education & $\begin{array}{c}0.033^{* *} \\
(0.012)\end{array}$ & $\begin{array}{l}0.055^{*} \\
(0.025)\end{array}$ & $\begin{array}{c}0.045 \\
(0.026)\end{array}$ & $\begin{array}{c}0.016 \\
(0.017)\end{array}$ & $\begin{array}{c}0.011 \\
(0.018)\end{array}$ & $\begin{array}{c}0.017 \\
(0.015)\end{array}$ & $\begin{array}{c}0.001 \\
(0.020)\end{array}$ \\
\hline Employment & $\begin{array}{l}-0.016 \\
(0.010)\end{array}$ & $\begin{array}{l}-0.013 \\
(0.009)\end{array}$ & $\begin{array}{c}-0.019^{* *} \\
(0.007)\end{array}$ & $\begin{array}{l}-0.008 \\
(0.019)\end{array}$ & $\begin{array}{l}-0.021 \\
(0.024)\end{array}$ & $\begin{array}{l}-0.018 \\
(0.017)\end{array}$ & $\begin{array}{l}-0.008 \\
(0.013)\end{array}$ \\
\hline Age & $\begin{array}{c}0.003^{* * *} \\
(0.001)\end{array}$ & $\begin{array}{c}0.003^{* *} \\
(0.001)\end{array}$ & $\begin{array}{c}0.002 \\
(0.001)\end{array}$ & $\begin{array}{l}-0.001^{*} \\
(0.001)\end{array}$ & $\begin{array}{l}-0.000 \\
(0.001)\end{array}$ & $\begin{array}{c}0.000 \\
(0.001)\end{array}$ & $\begin{array}{c}0.001 \\
(0.001)\end{array}$ \\
\hline Muslim & $\begin{array}{c}0.047 \\
(0.036)\end{array}$ & $\begin{array}{l}-0.022 \\
(0.059)\end{array}$ & $\begin{array}{l}-0.057 \\
(0.077)\end{array}$ & $\begin{array}{l}0.095^{*} \\
(0.047)\end{array}$ & $\begin{array}{c}0.054 \\
(0.031)\end{array}$ & $\begin{array}{l}-0.053 \\
(0.065)\end{array}$ & $\begin{array}{c}0.024 \\
(0.030)\end{array}$ \\
\hline Other Religion & $\begin{array}{l}-0.011 \\
(0.041)\end{array}$ & $\begin{array}{l}-0.059 \\
(0.065)\end{array}$ & $\begin{array}{l}-0.050 \\
(0.046)\end{array}$ & $\begin{array}{l}-0.066 \\
(0.058)\end{array}$ & $\begin{array}{l}-0.034 \\
(0.053)\end{array}$ & $\begin{array}{l}-0.089 \\
(0.050)\end{array}$ & $\begin{array}{c}0.031 \\
(0.036)\end{array}$ \\
\hline Ethnic Ewe & $\begin{array}{l}-0.034 \\
(0.057)\end{array}$ & $\begin{array}{l}-0.100 \\
(0.084)\end{array}$ & $\begin{array}{l}-0.105 \\
(0.062)\end{array}$ & $\begin{array}{l}-0.121 \\
(0.070)\end{array}$ & $\begin{array}{l}-0.076 \\
(0.068)\end{array}$ & $\begin{array}{l}-0.035 \\
(0.068)\end{array}$ & $\begin{array}{c}-0.183^{* * *} \\
(0.073)\end{array}$ \\
\hline Ethnic Ga & $\begin{array}{c}0.015 \\
(0.049)\end{array}$ & $\begin{array}{l}-0.073 \\
(0.047)\end{array}$ & $\begin{array}{l}-0.055 \\
(0.039)\end{array}$ & $\begin{array}{c}-0.090^{* *} \\
(0.032)\end{array}$ & $\begin{array}{l}-0.037 \\
(0.024)\end{array}$ & $\begin{array}{c}0.026 \\
(0.070)\end{array}$ & $\begin{array}{l}-0.060 \\
(0.037)\end{array}$ \\
\hline $\begin{array}{l}\text { Ethnic } \\
\text { Northern }\end{array}$ & $\begin{array}{c}0.053 \\
(0.054) \\
\end{array}$ & $\begin{array}{c}0.077 \\
(0.088) \\
\end{array}$ & $\begin{array}{c}0.010 \\
(0.075) \\
\end{array}$ & $\begin{array}{l}-0.090 \\
(0.074) \\
\end{array}$ & $\begin{array}{c}0.027 \\
(0.066) \\
\end{array}$ & $\begin{array}{c}0.080 \\
(0.071) \\
\end{array}$ & $\begin{array}{c}0.002 \\
(0.064) \\
\end{array}$ \\
\hline $\begin{array}{l}\text { Observations } \\
\text { R-squared }\end{array}$ & $\begin{array}{l}5,128 \\
0.457 \\
\end{array}$ & $\begin{array}{l}5,109 \\
0.384 \\
\end{array}$ & $\begin{array}{l}5,067 \\
0.266 \\
\end{array}$ & $\begin{array}{l}5,169 \\
0.326\end{array}$ & $\begin{array}{l}5,113 \\
0.284\end{array}$ & $\begin{array}{l}5,096 \\
0.225\end{array}$ & $\begin{array}{l}4,958 \\
0.309\end{array}$ \\
\hline
\end{tabular}


Table B2. Baseline Regression: Trust

\begin{tabular}{|c|c|c|c|c|c|c|}
\hline VARIABLES & $\begin{array}{c}(1) \\
\text { Trust President }\end{array}$ & $\begin{array}{c}(2) \\
\text { Trust } \\
\text { Parliament }\end{array}$ & $\begin{array}{c}(3) \\
\text { Trust Ruling } \\
\text { Party }\end{array}$ & $\begin{array}{c}(4) \\
\text { Trust Opp. } \\
\text { Party }\end{array}$ & $\begin{array}{c}(5) \\
\text { Trust Police }\end{array}$ & $\begin{array}{c}(6) \\
\text { Trust Courts }\end{array}$ \\
\hline NPP Partisan & $\begin{array}{l}1.099^{* * * *} \\
(0.082)\end{array}$ & $\begin{array}{l}0.554^{* * * *} \\
(0.057)\end{array}$ & $\begin{array}{l}1.125^{* * * *} \\
(0.086)\end{array}$ & $\begin{array}{c}-0.523^{* * *} \\
(0.085)\end{array}$ & $\begin{array}{l}0.270^{* * *} \\
(0.053)\end{array}$ & $\begin{array}{c}0.172^{* * *} \\
(0.030)\end{array}$ \\
\hline $\begin{array}{l}\text { Partisan } \\
\text { Divide }\end{array}$ & $\begin{array}{c}-2.413^{* * *} \\
(0.112)\end{array}$ & $\begin{array}{c}-1.189 * * * \\
(0.046)\end{array}$ & $\begin{array}{c}-2.377^{* * * *} \\
(0.140)\end{array}$ & $\begin{array}{c}1.055^{* * *} \\
(0.120)\end{array}$ & $\begin{array}{c}-0.614^{* * *} \\
(0.072)\end{array}$ & $\begin{array}{c}-0.534^{* * * *} \\
(0.045)\end{array}$ \\
\hline Gender & $\begin{array}{c}-0.052 \\
(0.031)\end{array}$ & $\begin{array}{l}-0.044 \\
(0.031)\end{array}$ & $\begin{array}{l}-0.054 \\
(0.057)\end{array}$ & $\begin{array}{c}-0.121 * * * \\
(0.025)\end{array}$ & $\begin{array}{c}-0.085^{* *} \\
(0.034)\end{array}$ & $\begin{array}{l}-0.037 \\
(0.031)\end{array}$ \\
\hline Location & $\begin{array}{l}0.091^{* *} \\
(0.039)\end{array}$ & $\begin{array}{l}0.079^{*} \\
(0.043)\end{array}$ & $\begin{array}{l}0.108^{*} \\
(0.057)\end{array}$ & $\begin{array}{c}0.044 \\
(0.037)\end{array}$ & $\begin{array}{l}0.148^{* *} \\
(0.059)\end{array}$ & $\begin{array}{c}0.142^{* * *} \\
(0.027)\end{array}$ \\
\hline Education & $\begin{array}{l}-0.017 \\
(0.016)\end{array}$ & $\begin{array}{l}-0.035 \\
(0.019)\end{array}$ & $\begin{array}{l}-0.007 \\
(0.022)\end{array}$ & $\begin{array}{c}-0.037 * * \\
(0.014)\end{array}$ & $\begin{array}{c}-0.077 * * * \\
(0.021)\end{array}$ & $\begin{array}{c}-0.042^{* * *} \\
(0.009)\end{array}$ \\
\hline Employment & $\begin{array}{c}0.005 \\
(0.012)\end{array}$ & $\begin{array}{l}-0.004 \\
(0.013)\end{array}$ & $\begin{array}{c}0.001 \\
(0.012)\end{array}$ & $\begin{array}{c}-0.011 \\
(0.011)\end{array}$ & $\begin{array}{c}-0.049 * * * \\
(0.015)\end{array}$ & $\begin{array}{c}0.001 \\
(0.018)\end{array}$ \\
\hline Age & $\begin{array}{c}0.005^{* * *} \\
(0.001)\end{array}$ & $\begin{array}{c}0.005^{* * *} \\
(0.001)\end{array}$ & $\begin{array}{c}0.004^{* * *} \\
(0.000)\end{array}$ & $\begin{array}{c}0.003^{* * *} \\
(0.001)\end{array}$ & $\begin{array}{l}0.003^{*} \\
(0.001)\end{array}$ & $\begin{array}{c}0.001 \\
(0.001)\end{array}$ \\
\hline Muslim & $\begin{array}{l}-0.093 \\
(0.072)\end{array}$ & $\begin{array}{c}-0.111 \\
(0.078)\end{array}$ & $\begin{array}{l}-0.077^{*} \\
(0.041)\end{array}$ & $\begin{array}{c}0.063 \\
(0.064)\end{array}$ & $\begin{array}{l}-0.051 \\
(0.094)\end{array}$ & $\begin{array}{c}0.025 \\
(0.090)\end{array}$ \\
\hline Other Religion & $\begin{array}{l}-0.046 \\
(0.051)\end{array}$ & $\begin{array}{c}-0.044 \\
(0.060)\end{array}$ & $\begin{array}{c}0.007 \\
(0.054)\end{array}$ & $\begin{array}{c}0.004 \\
(0.046)\end{array}$ & $\begin{array}{c}0.029 \\
(0.109)\end{array}$ & $\begin{array}{c}0.012 \\
(0.062)\end{array}$ \\
\hline Ethnic Ewe & $\begin{array}{c}0.042 \\
(0.068)\end{array}$ & $\begin{array}{l}-0.040 \\
(0.062)\end{array}$ & $\begin{array}{l}-0.074 \\
(0.080)\end{array}$ & $\begin{array}{l}-0.071 \\
(0.045)\end{array}$ & $\begin{array}{c}0.029 \\
(0.061)\end{array}$ & $\begin{array}{c}0.018 \\
(0.035)\end{array}$ \\
\hline Ethnic Ga & $\begin{array}{l}-0.079 \\
(0.066)\end{array}$ & $\begin{array}{c}-0.081^{* *} \\
(0.032)\end{array}$ & $\begin{array}{c}-0.069^{* *} \\
(0.026)\end{array}$ & $\begin{array}{c}-0.191^{* *} \\
(0.067)\end{array}$ & $\begin{array}{l}-0.047^{*} \\
(0.025)\end{array}$ & $\begin{array}{l}-0.051 \\
(0.036)\end{array}$ \\
\hline $\begin{array}{l}\text { Ethnic } \\
\text { Northern }\end{array}$ & $\begin{array}{c}0.106^{* * *} \\
(0.030)\end{array}$ & $\begin{array}{c}0.013 \\
(0.054) \\
\end{array}$ & $\begin{array}{c}0.039 \\
(0.093) \\
\end{array}$ & $\begin{array}{c}0.002 \\
(0.102) \\
\end{array}$ & $\begin{array}{c}0.056 \\
(0.071) \\
\end{array}$ & $\begin{array}{c}-0.001 \\
(0.067) \\
\end{array}$ \\
\hline Observations & 5,166 & 5,096 & 5,157 & 5,080 & 5,179 & 5,098 \\
\hline R-squared & 0.400 & 0.184 & 0.366 & 0.110 & 0.105 & 0.100 \\
\hline
\end{tabular}


Table B3. Baseline Regression: Perceived Living and Economic Conditions

\begin{tabular}{|c|c|c|c|c|}
\hline VARIABLES & $\begin{array}{c}\text { (1) } \\
\text { Living Cond. } \\
\text { (absolute) }\end{array}$ & $\begin{array}{c}(2) \\
\text { Living Cond. } \\
\text { (relative) }\end{array}$ & $\begin{array}{c}(3) \\
\text { Economic Cond. } \\
\text { (Present) }\end{array}$ & $\begin{array}{c}(4) \\
\text { Economic Cond. } \\
\text { (Future) }\end{array}$ \\
\hline $\begin{array}{l}\text { NPP Partisan } \\
\text { Partisan } \\
\text { Divide }\end{array}$ & $\begin{array}{c}0.568^{* * *} \\
(0.076) \\
-1.161^{* * *} \\
(0.141)\end{array}$ & $\begin{array}{c}0.317 * * * \\
(0.057) \\
-0.650 * * * \\
(0.101)\end{array}$ & $\begin{array}{c}0.828 * * * \\
(0.087) \\
-1.622^{* * *} \\
(0.169)\end{array}$ & $\begin{array}{c}0.624^{* * *} \\
(0.080) \\
-1.317^{* * *} \\
(0.146)\end{array}$ \\
\hline Gender & $\begin{array}{c}-0.018 \\
(0.026)\end{array}$ & $\begin{array}{c}-0.034 \\
(0.026)\end{array}$ & $\begin{array}{c}-0.040 \\
(0.028)\end{array}$ & $\begin{array}{c}-0.058^{* *} \\
(0.023)\end{array}$ \\
\hline Location & $\begin{array}{c}-0.161^{* *} \\
(0.065)\end{array}$ & $\begin{array}{c}-0.155^{* * * *} \\
(0.043)\end{array}$ & $\begin{array}{l}-0.034 \\
(0.048)\end{array}$ & $\begin{array}{c}0.000 \\
(0.067)\end{array}$ \\
\hline Education & $\begin{array}{c}0.148^{* * * *} \\
(0.030)\end{array}$ & $\begin{array}{c}0.160 * * * \\
(0.029)\end{array}$ & $\begin{array}{c}0.125^{* * *} \\
(0.016)\end{array}$ & $\begin{array}{c}0.061^{* * *} \\
(0.015)\end{array}$ \\
\hline Employment & $\begin{array}{l}-0.034^{*} \\
(0.015)\end{array}$ & $\begin{array}{l}-0.014 \\
(0.015)\end{array}$ & $\begin{array}{l}-0.035^{*} \\
(0.018)\end{array}$ & $\begin{array}{l}-0.001 \\
(0.012)\end{array}$ \\
\hline Age & $\begin{array}{l}-0.002^{*} \\
(0.001)\end{array}$ & $\begin{array}{l}-0.002 \\
(0.001)\end{array}$ & $\begin{array}{c}-0.001 \\
(0.001)\end{array}$ & $\begin{array}{l}-0.003^{*} \\
(0.001)\end{array}$ \\
\hline Muslim & $\begin{array}{c}0.067 \\
(0.063)\end{array}$ & $\begin{array}{c}0.162 * * * \\
(0.042)\end{array}$ & $\begin{array}{l}-0.008 \\
(0.048)\end{array}$ & $\begin{array}{c}0.071 \\
(0.041)\end{array}$ \\
\hline Other Religion & $\begin{array}{l}-0.114 \\
(0.089)\end{array}$ & $\begin{array}{c}-0.115^{* *} \\
(0.039)\end{array}$ & $\begin{array}{l}-0.080 \\
(0.081)\end{array}$ & $\begin{array}{l}-0.050 \\
(0.072)\end{array}$ \\
\hline Ethnic Ewe & $\begin{array}{l}-0.127 \\
(0.086)\end{array}$ & $\begin{array}{c}0.016 \\
(0.069)\end{array}$ & $\begin{array}{l}-0.097 \\
(0.083)\end{array}$ & $\begin{array}{l}-0.104 \\
(0.059)\end{array}$ \\
\hline Ethnic Ga & $\begin{array}{l}-0.124 \\
(0.111)\end{array}$ & $\begin{array}{l}-0.052 \\
(0.051)\end{array}$ & $\begin{array}{l}-0.031 \\
(0.082)\end{array}$ & $\begin{array}{c}-0.142^{* *} \\
(0.062)\end{array}$ \\
\hline $\begin{array}{l}\text { Ethnic } \\
\text { Northern }\end{array}$ & $\begin{array}{c}0.040 \\
(0.076)\end{array}$ & $\begin{array}{c}0.094 \\
(0.069) \\
\end{array}$ & $\begin{array}{c}-0.024 \\
(0.074) \\
\end{array}$ & $\begin{array}{c}-0.112 \\
(0.069) \\
\end{array}$ \\
\hline $\begin{array}{l}\text { Observations } \\
\text { R-squared }\end{array}$ & $\begin{array}{l}5,217 \\
0.137\end{array}$ & $\begin{array}{l}4,960 \\
0.093\end{array}$ & $\begin{array}{l}5,183 \\
0.206\end{array}$ & $\begin{array}{l}4,530 \\
0.284\end{array}$ \\
\hline
\end{tabular}


Table B4. Baseline Regression: Political Perceptions

\begin{tabular}{|c|c|c|c|c|c|c|}
\hline VARIABLES & $\begin{array}{c}(1) \\
\text { Corruption } \\
\text { President }\end{array}$ & $\begin{array}{c}(2) \\
\text { Corruption } \\
\text { MPs }\end{array}$ & $\begin{array}{c}(3) \\
\text { Corruption } \\
\text { Police }\end{array}$ & $\begin{array}{c}(4) \\
\text { Corruption } \\
\text { Judges }\end{array}$ & $\begin{array}{c}(5) \\
\text { Fear of Crime }\end{array}$ & $\begin{array}{c}(6) \\
\text { Unfair Gov. } \\
\text { Treatment }\end{array}$ \\
\hline NPP Partisan & $\begin{array}{c}-0.171^{* * *} \\
(0.020)\end{array}$ & $\begin{array}{c}-0.124^{* * *} \\
(0.013)\end{array}$ & $\begin{array}{c}-0.048^{* *} \\
(0.016)\end{array}$ & $\begin{array}{c}-0.055^{* * *} \\
(0.011)\end{array}$ & $\begin{array}{l}-0.084^{*} \\
(0.045)\end{array}$ & $\begin{array}{c}-0.358^{* * *} \\
(0.050)\end{array}$ \\
\hline $\begin{array}{l}\text { Partisan } \\
\text { Divide }\end{array}$ & $\begin{array}{c}0.417^{* * * *} \\
(0.034)\end{array}$ & $\begin{array}{c}0.289 * * * \\
(0.033)\end{array}$ & $\begin{array}{c}0.187^{* * * *} \\
(0.019)\end{array}$ & $\begin{array}{c}0.201 * * * \\
(0.032)\end{array}$ & $\begin{array}{c}0.168^{* *} \\
(0.068)\end{array}$ & $\begin{array}{c}0.706^{* * *} \\
(0.141)\end{array}$ \\
\hline Gender & $\begin{array}{l}-0.015 \\
(0.014)\end{array}$ & $\begin{array}{l}-0.028^{*} \\
(0.013)\end{array}$ & $\begin{array}{l}-0.001 \\
(0.014)\end{array}$ & $\begin{array}{l}-0.016 \\
(0.014)\end{array}$ & $\begin{array}{l}0.048^{* *} \\
(0.020)\end{array}$ & $\begin{array}{l}-0.043^{*} \\
(0.021)\end{array}$ \\
\hline Location & $\begin{array}{c}-0.028^{* *} \\
(0.012)\end{array}$ & $\begin{array}{l}-0.015 \\
(0.011)\end{array}$ & $\begin{array}{c}0.005 \\
(0.011)\end{array}$ & $\begin{array}{l}-0.006 \\
(0.020)\end{array}$ & $\begin{array}{l}-0.128^{* *} \\
(0.047)\end{array}$ & $\begin{array}{c}0.019 \\
(0.030)\end{array}$ \\
\hline Education & $\begin{array}{c}0.006 \\
(0.009)\end{array}$ & $\begin{array}{l}-0.013 \\
(0.011)\end{array}$ & $\begin{array}{l}0.018^{*} \\
(0.008)\end{array}$ & $\begin{array}{l}-0.001 \\
(0.010)\end{array}$ & $\begin{array}{l}-0.004 \\
(0.017)\end{array}$ & $\begin{array}{l}-0.001 \\
(0.020)\end{array}$ \\
\hline Employment & $\begin{array}{l}0.016^{* *} \\
(0.007)\end{array}$ & $\begin{array}{l}0.014^{* *} \\
(0.005)\end{array}$ & $\begin{array}{c}0.012 \\
(0.007)\end{array}$ & $\begin{array}{l}0.009^{*} \\
(0.005)\end{array}$ & $\begin{array}{c}-0.001 \\
(0.012)\end{array}$ & $\begin{array}{l}-0.007 \\
(0.013)\end{array}$ \\
\hline Age & $\begin{array}{c}-0.002^{* * * *} \\
(0.000)\end{array}$ & $\begin{array}{c}-0.002^{* * * *} \\
(0.000)\end{array}$ & $\begin{array}{l}-0.000 \\
(0.000)\end{array}$ & $\begin{array}{l}-0.001^{*} \\
(0.000)\end{array}$ & $\begin{array}{l}-0.001 \\
(0.001)\end{array}$ & $\begin{array}{c}0.000 \\
(0.000)\end{array}$ \\
\hline Muslim & $\begin{array}{c}0.005 \\
(0.026)\end{array}$ & $\begin{array}{c}0.042 \\
(0.030)\end{array}$ & $\begin{array}{c}0.007 \\
(0.030)\end{array}$ & $\begin{array}{l}-0.031 \\
(0.024)\end{array}$ & $\begin{array}{c}0.159^{* *} \\
(0.056)\end{array}$ & $\begin{array}{c}0.018 \\
(0.040)\end{array}$ \\
\hline Other Religion & $\begin{array}{c}0.001 \\
(0.026)\end{array}$ & $\begin{array}{c}0.011 \\
(0.019)\end{array}$ & $\begin{array}{l}-0.027 \\
(0.034)\end{array}$ & $\begin{array}{l}-0.036 \\
(0.043)\end{array}$ & $\begin{array}{c}0.054 \\
(0.047)\end{array}$ & $\begin{array}{l}0.117^{* * *} \\
(0.045)\end{array}$ \\
\hline Ethnic Ewe & $\begin{array}{l}-0.011 \\
(0.024)\end{array}$ & $\begin{array}{l}-0.014 \\
(0.029)\end{array}$ & $\begin{array}{c}0.019 \\
(0.034)\end{array}$ & $\begin{array}{l}-0.049 \\
(0.039)\end{array}$ & $\begin{array}{l}0.107^{* *} \\
(0.040)\end{array}$ & $\begin{array}{l}-0.083 \\
(0.085)\end{array}$ \\
\hline Ethnic Ga & $\begin{array}{c}0.000 \\
(0.024)\end{array}$ & $\begin{array}{l}-0.000 \\
(0.026)\end{array}$ & $\begin{array}{c}0.007 \\
(0.014)\end{array}$ & $\begin{array}{l}-0.016 \\
(0.029)\end{array}$ & $\begin{array}{c}0.010 \\
(0.039)\end{array}$ & $\begin{array}{c}0.052 \\
(0.091)\end{array}$ \\
\hline $\begin{array}{l}\text { Ethnic } \\
\text { Northern }\end{array}$ & $\begin{array}{c}-0.077^{* * *} \\
(0.021)\end{array}$ & $\begin{array}{c}-0.073^{* * *} \\
(0.021)\end{array}$ & $\begin{array}{c}-0.042 \\
(0.032) \\
\end{array}$ & $\begin{array}{l}-0.017 \\
(0.036)\end{array}$ & $\begin{array}{c}-0.102 \\
(0.072)\end{array}$ & $\begin{array}{r}-0.010 \\
(0.084) \\
\end{array}$ \\
\hline $\begin{array}{l}\text { Observations } \\
\text { R-squared }\end{array}$ & $\begin{array}{l}5,240 \\
0.156\end{array}$ & $\begin{array}{l}5,240 \\
0.110\end{array}$ & $\begin{array}{l}5,240 \\
0.026\end{array}$ & $\begin{array}{l}5,240 \\
0.055\end{array}$ & $\begin{array}{l}5,229 \\
0.039\end{array}$ & $\begin{array}{l}4,927 \\
0.102\end{array}$ \\
\hline
\end{tabular}


Table B5. Baseline Regression: Political Attitudes

\begin{tabular}{|c|c|c|c|c|c|}
\hline VARIABLES & $\begin{array}{c}\quad(1) \\
\text { Freedom of } \\
\text { Association }\end{array}$ & $\begin{array}{c}(2) \\
\text { Freedom of Press }\end{array}$ & $\begin{array}{c}(3) \\
\text { One-Party Rule }\end{array}$ & $\begin{array}{c}(4) \\
\text { One-Man Rule }\end{array}$ & $\begin{array}{c}(5) \\
\text { Electoral } \\
\text { Democracy }\end{array}$ \\
\hline NPP Partisan & $\begin{array}{c}-0.261^{* * *} \\
(0.048)\end{array}$ & $\begin{array}{l}-0.089^{* *} \\
(0.035)\end{array}$ & $\begin{array}{l}0.194^{* *} \\
(0.068)\end{array}$ & $\begin{array}{c}0.056 \\
(0.044)\end{array}$ & $\begin{array}{l}-0.099^{*} \\
(0.047)\end{array}$ \\
\hline $\begin{array}{l}\text { Partisan } \\
\text { Divide }\end{array}$ & $\begin{array}{c}0.483^{* * *} \\
(0.097)\end{array}$ & $\begin{array}{l}-0.153 \\
(0.093)\end{array}$ & $\begin{array}{c}-0.433^{* * *} \\
(0.115)\end{array}$ & $\begin{array}{c}-0.254^{* * *} \\
(0.063)\end{array}$ & $\begin{array}{c}0.032 \\
(0.054)\end{array}$ \\
\hline Gender & $\begin{array}{l}-0.057 * * \\
(0.025)\end{array}$ & $\begin{array}{l}-0.003 \\
(0.031)\end{array}$ & $\begin{array}{c}0.133^{* * *} \\
(0.034)\end{array}$ & $\begin{array}{l}0.071^{* *} \\
(0.024)\end{array}$ & $\begin{array}{c}0.055^{* * *} \\
(0.015)\end{array}$ \\
\hline Location & $\begin{array}{l}-0.050 \\
(0.035)\end{array}$ & $\begin{array}{l}-0.031 \\
(0.036)\end{array}$ & $\begin{array}{l}0.074^{*} \\
(0.033)\end{array}$ & $\begin{array}{l}0.075^{*} \\
(0.040)\end{array}$ & $\begin{array}{l}-0.001 \\
(0.022)\end{array}$ \\
\hline Education & $\begin{array}{c}0.093 * * * \\
(0.011)\end{array}$ & $\begin{array}{c}0.032 \\
(0.023)\end{array}$ & $\begin{array}{l}-0.158^{* * *} \\
(0.031)\end{array}$ & $\begin{array}{c}-0.072^{* * *} \\
(0.015)\end{array}$ & $\begin{array}{c}-0.056^{* *} \\
(0.021)\end{array}$ \\
\hline Employment & $\begin{array}{l}-0.011 \\
(0.025)\end{array}$ & $\begin{array}{l}-0.004 \\
(0.023)\end{array}$ & $\begin{array}{l}-0.016 \\
(0.016)\end{array}$ & $\begin{array}{c}0.021 \\
(0.015)\end{array}$ & $\begin{array}{c}0.008 \\
(0.018)\end{array}$ \\
\hline Age & $\begin{array}{l}0.003^{*} \\
(0.002)\end{array}$ & $\begin{array}{l}-0.001 \\
(0.001)\end{array}$ & $\begin{array}{c}-0.004^{* * * *} \\
(0.001)\end{array}$ & $\begin{array}{l}-0.002^{* *} \\
(0.001)\end{array}$ & $\begin{array}{c}-0.002^{* *} \\
(0.001)\end{array}$ \\
\hline Muslim & $\begin{array}{l}-0.036 \\
(0.051)\end{array}$ & $\begin{array}{c}0.100 \\
(0.082)\end{array}$ & $\begin{array}{c}0.001 \\
(0.054)\end{array}$ & $\begin{array}{c}0.016 \\
(0.048)\end{array}$ & $\begin{array}{c}0.042 \\
(0.041)\end{array}$ \\
\hline Other Religion & $\begin{array}{c}0.021 \\
(0.096)\end{array}$ & $\begin{array}{c}0.072 \\
(0.110)\end{array}$ & $\begin{array}{c}0.129 \\
(0.074)\end{array}$ & $\begin{array}{l}0.110^{*} \\
(0.053)\end{array}$ & $\begin{array}{c}0.098 \\
(0.070)\end{array}$ \\
\hline Ethnic Ewe & $\begin{array}{c}-0.162^{* *} \\
(0.058)\end{array}$ & $\begin{array}{c}0.022 \\
(0.037)\end{array}$ & $\begin{array}{c}0.017 \\
(0.063)\end{array}$ & $\begin{array}{l}-0.040 \\
(0.075)\end{array}$ & $\begin{array}{c}0.025 \\
(0.049)\end{array}$ \\
\hline Ethnic Ga & $\begin{array}{c}0.067 \\
(0.071)\end{array}$ & $\begin{array}{l}-0.069 \\
(0.049)\end{array}$ & $\begin{array}{c}0.002 \\
(0.057)\end{array}$ & $\begin{array}{c}0.031 \\
(0.029)\end{array}$ & $\begin{array}{l}-0.060 \\
(0.039)\end{array}$ \\
\hline $\begin{array}{l}\text { Ethnic } \\
\text { Northern }\end{array}$ & $\begin{array}{c}0.075 \\
(0.068) \\
\end{array}$ & $\begin{array}{c}0.018 \\
(0.052)\end{array}$ & $\begin{array}{l}-0.052 \\
(0.089)\end{array}$ & $\begin{array}{c}0.007 \\
(0.096)\end{array}$ & $\begin{array}{l}-0.006 \\
(0.061)\end{array}$ \\
\hline $\begin{array}{l}\text { Observations } \\
\text { R-squared }\end{array}$ & $\begin{array}{l}4,477 \\
0.037\end{array}$ & $\begin{array}{l}4,517 \\
0.076\end{array}$ & $\begin{array}{l}5,196 \\
0.039\end{array}$ & $\begin{array}{l}5,161 \\
0.039\end{array}$ & $\begin{array}{l}5,166 \\
0.033\end{array}$ \\
\hline
\end{tabular}


Table B6. Robustness Tests

\begin{tabular}{|c|c|c|c|c|c|}
\hline VARIABLES & $\begin{array}{c}\text { (1) } \\
\text { Public Utility } \\
\text { Index }\end{array}$ & $\begin{array}{c}(2) \\
\text { Asset Index }\end{array}$ & $\begin{array}{c}(3) \\
\text { Bribe Police }\end{array}$ & $\begin{array}{c}(4) \\
\text { Bribe Document }\end{array}$ & $\begin{array}{c}(5) \\
\text { Attacked }\end{array}$ \\
\hline NPP Partisan & $\begin{array}{l}0.112^{* *} \\
(0.042)\end{array}$ & $\begin{array}{c}0.110 \\
(0.108)\end{array}$ & $\begin{array}{l}0.119^{*} \\
(0.055)\end{array}$ & $\begin{array}{c}0.025 \\
(0.041)\end{array}$ & $\begin{array}{l}-0.013 \\
(0.016)\end{array}$ \\
\hline $\begin{array}{l}\text { Partisan } \\
\text { Divide }\end{array}$ & $\begin{array}{l}-0.025 \\
(0.065)\end{array}$ & $\begin{array}{l}-0.066 \\
(0.100)\end{array}$ & $\begin{array}{l}-0.025 \\
(0.107)\end{array}$ & $\begin{array}{c}0.031 \\
(0.040)\end{array}$ & $\begin{array}{c}0.046 \\
(0.033)\end{array}$ \\
\hline Gender & $\begin{array}{l}0.048^{*} \\
(0.024)\end{array}$ & $\begin{array}{c}-0.298 * * * \\
(0.035)\end{array}$ & $\begin{array}{c}-0.113^{* *} \\
(0.036)\end{array}$ & $\begin{array}{c}-0.142^{* * *} \\
(0.034)\end{array}$ & $\begin{array}{l}-0.013 \\
(0.011)\end{array}$ \\
\hline Location & $\begin{array}{c}-1.195^{* * * *} \\
(0.124)\end{array}$ & $\begin{array}{c}-0.381 * * * \\
(0.047)\end{array}$ & $\begin{array}{l}-0.056 \\
(0.046)\end{array}$ & $\begin{array}{l}-0.100 * * \\
(0.036)\end{array}$ & $\begin{array}{l}-0.003 \\
(0.018)\end{array}$ \\
\hline Education & $\begin{array}{c}0.138^{* * *} \\
(0.031)\end{array}$ & $\begin{array}{l}0.292^{* * *} \\
(0.016)\end{array}$ & $\begin{array}{l}0.049^{* *} \\
(0.018)\end{array}$ & $\begin{array}{c}0.066^{* * *} \\
(0.014)\end{array}$ & $\begin{array}{c}0.011 \\
(0.013)\end{array}$ \\
\hline Employment & $\begin{array}{l}-0.022 \\
(0.019)\end{array}$ & $\begin{array}{c}0.138 * * * \\
(0.020)\end{array}$ & $\begin{array}{l}0.032^{* *} \\
(0.014)\end{array}$ & $\begin{array}{l}0.039^{* * *} \\
(0.012)\end{array}$ & $\begin{array}{l}-0.007 \\
(0.006)\end{array}$ \\
\hline Age & $\begin{array}{l}-0.000 \\
(0.001)\end{array}$ & $\begin{array}{l}0.004^{* * *} \\
(0.001)\end{array}$ & $\begin{array}{l}-0.000 \\
(0.001)\end{array}$ & $\begin{array}{c}0.001 \\
(0.001)\end{array}$ & $\begin{array}{c}-0.002^{* * *} \\
(0.000)\end{array}$ \\
\hline Muslim & $\begin{array}{c}0.152 \\
(0.108)\end{array}$ & $\begin{array}{l}0.129 * * * \\
(0.038)\end{array}$ & $\begin{array}{c}0.068 \\
(0.099)\end{array}$ & $\begin{array}{c}0.012 \\
(0.057)\end{array}$ & $\begin{array}{c}0.034 \\
(0.023)\end{array}$ \\
\hline Other Religion & $\begin{array}{l}-0.130 \\
(0.088)\end{array}$ & $\begin{array}{c}-0.269 * * * \\
(0.042)\end{array}$ & $\begin{array}{l}-0.012 \\
(0.065)\end{array}$ & $\begin{array}{c}-0.108^{* *} \\
(0.034)\end{array}$ & $\begin{array}{c}0.052 \\
(0.034)\end{array}$ \\
\hline Ethnic Ewe & $\begin{array}{l}-0.226 \\
(0.186)\end{array}$ & $\begin{array}{c}0.047 \\
(0.098)\end{array}$ & $\begin{array}{c}0.055 \\
(0.093)\end{array}$ & $\begin{array}{c}0.095 \\
(0.081)\end{array}$ & $\begin{array}{c}0.032 \\
(0.024)\end{array}$ \\
\hline Ethnic Ga & $\begin{array}{l}-0.185 \\
(0.129)\end{array}$ & $\begin{array}{l}-0.056 \\
(0.073)\end{array}$ & $\begin{array}{c}0.000 \\
(0.103)\end{array}$ & $\begin{array}{c}0.014 \\
(0.049)\end{array}$ & $\begin{array}{c}0.036 \\
(0.020)\end{array}$ \\
\hline $\begin{array}{l}\text { Ethnic } \\
\text { Northern }\end{array}$ & $\begin{array}{c}-0.383^{* *} \\
(0.155) \\
\end{array}$ & $\begin{array}{c}0.028 \\
(0.077)\end{array}$ & $\begin{array}{c}0.095 \\
(0.089)\end{array}$ & $\begin{array}{c}0.013 \\
(0.057)\end{array}$ & $\begin{array}{l}-0.007 \\
(0.029)\end{array}$ \\
\hline $\begin{array}{l}\text { Observations } \\
\text { R-squared }\end{array}$ & $\begin{array}{l}5,129 \\
0.395\end{array}$ & $\begin{array}{l}4,658 \\
0.527\end{array}$ & $\begin{array}{l}2,676 \\
0.111\end{array}$ & $\begin{array}{l}2,381 \\
0.090\end{array}$ & $\begin{array}{l}5,237 \\
0.023\end{array}$ \\
\hline
\end{tabular}


Table B7. Robustness Tests: Geographic Identification

\begin{tabular}{|c|c|c|c|c|c|c|c|}
\hline VARIABLES & $\begin{array}{c}(1) \\
\text { Performance } \\
\text { President }\end{array}$ & $\begin{array}{c}(2) \\
\text { Satisfaction } \\
\text { (Economy) }\end{array}$ & $\begin{array}{c}(3) \\
\text { Satisfaction } \\
\text { (Jobs) }\end{array}$ & $\begin{array}{c}\text { (4) } \\
\text { Satisfaction } \\
\text { (Education) }\end{array}$ & $\begin{array}{c}\text { (5) } \\
\text { Satisfaction } \\
\text { (Health) }\end{array}$ & $\begin{array}{c}(6) \\
\text { Satisfaction } \\
\text { (Crime) }\end{array}$ & $\begin{array}{c}(7) \\
\text { Satisfaction } \\
\text { (Corruption) }\end{array}$ \\
\hline NPP Partisan & $\begin{array}{c}0.633^{* * *} \\
(0.166)\end{array}$ & $\begin{array}{l}0.517^{* *} \\
(0.221)\end{array}$ & $\begin{array}{c}0.538^{* * *} \\
(0.099)\end{array}$ & $\begin{array}{c}0.382^{* * *} \\
(0.062)\end{array}$ & $\begin{array}{c}0.189 \\
(0.144)\end{array}$ & $\begin{array}{c}0.323^{* * *} \\
(0.024)\end{array}$ & $\begin{array}{c}0.418^{* * *} \\
(0.024)\end{array}$ \\
\hline $\begin{array}{l}\text { Partisan } \\
\text { Divide }\end{array}$ & $\begin{array}{c}-2.165^{* * *} \\
(0.187)\end{array}$ & $\begin{array}{c}-1.916^{* * *} \\
(0.202)\end{array}$ & $\begin{array}{c}-1.735^{* * *} \\
(0.215)\end{array}$ & $\begin{array}{c}-1.601^{* * *} \\
(0.184)\end{array}$ & $\begin{array}{c}-1.575^{* * *} \\
(0.156)\end{array}$ & $\begin{array}{c}-1.579^{* * *} \\
(0.144)\end{array}$ & $\begin{array}{c}-1.733^{* * *} \\
(0.148)\end{array}$ \\
\hline $\begin{array}{l}\text { Controls } \\
\text { Observations } \\
\text { R-squared }\end{array}$ & $\begin{array}{c}\text { YES } \\
2,543 \\
0.415 \\
\end{array}$ & $\begin{array}{r}\text { YES } \\
2,555 \\
0.375 \\
\end{array}$ & $\begin{array}{c}\text { YES } \\
2,500 \\
0.273 \\
\end{array}$ & $\begin{array}{c}\text { YES } \\
2,579 \\
0.361 \\
\end{array}$ & $\begin{array}{c}\text { YES } \\
2,559 \\
0.302 \\
\end{array}$ & $\begin{array}{l}\text { YES } \\
2,543 \\
0.209\end{array}$ & $\begin{array}{l}\text { YES } \\
2,455 \\
0.334\end{array}$ \\
\hline VARIABLES & $\begin{array}{c}(8) \\
\text { Trust } \\
\text { President }\end{array}$ & $\begin{array}{c}\text { (9) } \\
\text { Trust } \\
\text { Parliament }\end{array}$ & $\begin{array}{c}(10) \\
\text { Trust Ruling } \\
\text { Party }\end{array}$ & $\begin{array}{c}\text { (11) } \\
\text { Trust } \\
\text { Opposition } \\
\text { Party }\end{array}$ & $\begin{array}{l}(12) \\
\text { Trust } \\
\text { Police }\end{array}$ & $\begin{array}{c}\text { (13) } \\
\text { Trust } \\
\text { Courts }\end{array}$ & $\begin{array}{c}\text { (14) } \\
\text { Living } \\
\text { Conditions } \\
\text { (absolute) }\end{array}$ \\
\hline NPP Partisan & $\begin{array}{l}0.306^{*} \\
(0.149)\end{array}$ & $\begin{array}{l}0.230^{* * *} \\
(0.095)\end{array}$ & $\begin{array}{c}0.359^{* * *} \\
(0.075)\end{array}$ & $\begin{array}{l}-0.098 \\
(0.104)\end{array}$ & $\begin{array}{c}0.159 \\
(0.131)\end{array}$ & $\begin{array}{c}0.026 \\
(0.113)\end{array}$ & $\begin{array}{l}0.470^{*} \\
(0.207)\end{array}$ \\
\hline $\begin{array}{l}\text { Partisan } \\
\text { Divide }\end{array}$ & $\begin{array}{c}-1.850^{* * *} \\
(0.157)\end{array}$ & $\begin{array}{c}-0.786^{* * * *} \\
(0.084)\end{array}$ & $\begin{array}{c}-1.726^{* * *} \\
(0.152)\end{array}$ & $\begin{array}{c}0.993^{* * *} \\
(0.186)\end{array}$ & $\begin{array}{c}-0.349^{* * * *} \\
(0.064)\end{array}$ & $\begin{array}{c}-0.378^{* * *} \\
(0.059)\end{array}$ & $\begin{array}{c}-1.045^{* * *} \\
(0.046)\end{array}$ \\
\hline $\begin{array}{l}\text { Controls } \\
\text { Observations } \\
\text { R-squared }\end{array}$ & $\begin{array}{l}\text { YES } \\
2,569 \\
0.296\end{array}$ & $\begin{array}{c}\text { YES } \\
2,528 \\
0.137\end{array}$ & $\begin{array}{l}\text { YES } \\
2,540 \\
0.269\end{array}$ & $\begin{array}{l}\text { YES } \\
2,511 \\
0.108\end{array}$ & $\begin{array}{l}\text { YES } \\
2,583 \\
0.074\end{array}$ & $\begin{array}{c}\text { YES } \\
2,543 \\
0.073\end{array}$ & $\begin{array}{c}\text { YES } \\
2,614 \\
0.133\end{array}$ \\
\hline
\end{tabular}


Table B8. Robustness Tests: Geographic Identification

\begin{tabular}{|c|c|c|c|c|c|c|c|}
\hline VARIABLES & $\begin{array}{c}1) \\
\text { Living } \\
\text { Conditions } \\
\text { (relative) } \\
\end{array}$ & $\begin{array}{c}(2) \\
\text { Economic } \\
\text { Conditions } \\
\text { (Present) } \\
\end{array}$ & $\begin{array}{c}(3) \\
\text { Economic } \\
\text { Conditions } \\
\text { (Future) } \\
\end{array}$ & $\begin{array}{c}\text { (4) } \\
\text { Corruption } \\
\text { President }\end{array}$ & $\begin{array}{c}(5) \\
\text { Corruption } \\
\text { MPs }\end{array}$ & $\begin{array}{c}(6) \\
\text { Corruption } \\
\text { Police }\end{array}$ & $\begin{array}{c}(7) \\
\text { Corruption } \\
\text { Judges }\end{array}$ \\
\hline NPP Partisan & $\begin{array}{l}0.376^{* *} \\
(0.136)\end{array}$ & $\begin{array}{l}0.706 * * * \\
(0.154)\end{array}$ & $\begin{array}{c}0.448 \\
(0.261)\end{array}$ & $\begin{array}{l}-0.056 \\
(0.061)\end{array}$ & $\begin{array}{c}-0.089 * * \\
(0.036)\end{array}$ & $\begin{array}{l}0.034^{*} \\
(0.016)\end{array}$ & $\begin{array}{c}0.037 \\
(0.034)\end{array}$ \\
\hline $\begin{array}{l}\text { Partisan } \\
\text { Divide }\end{array}$ & $\begin{array}{c}-0.818 * * * \\
(0.074)\end{array}$ & $\begin{array}{c}-1.450 * * * \\
(0.097)\end{array}$ & $\begin{array}{c}-1.372^{* * *} \\
(0.183)\end{array}$ & $\begin{array}{c}0.267 * * * \\
(0.028)\end{array}$ & $\begin{array}{c}0.182^{* * *} \\
(0.022)\end{array}$ & $\begin{array}{c}0.125^{* * *} \\
(0.020)\end{array}$ & $\begin{array}{l}0.121 * * * \\
(0.025)\end{array}$ \\
\hline $\begin{array}{l}\text { Controls } \\
\text { Observations } \\
\text { R-squared }\end{array}$ & $\begin{array}{c}\text { YES } \\
2,462 \\
0.114 \\
\end{array}$ & $\begin{array}{l}\text { YES } \\
2,580 \\
0.196 \\
\end{array}$ & $\begin{array}{c}\text { YES } \\
2,232 \\
0.257 \\
\end{array}$ & $\begin{array}{c}\text { YES } \\
2,629 \\
0.111 \\
\end{array}$ & $\begin{array}{l}\text { YES } \\
2,629 \\
0.094 \\
\end{array}$ & $\begin{array}{c}\text { YES } \\
2,629 \\
0.023 \\
\end{array}$ & $\begin{array}{l}\text { YES } \\
2,629 \\
0.047 \\
\end{array}$ \\
\hline VARIABLES & Fear of Crime & $\begin{array}{c}\text { (9) } \\
\text { Unfair Gov. } \\
\text { Treatment }\end{array}$ & $\begin{array}{c}\text { (10) } \\
\text { Freedom of } \\
\text { Association }\end{array}$ & $\begin{array}{c}(11) \\
\text { Freedom of } \\
\text { Press }\end{array}$ & $\begin{array}{c}(12) \\
\text { One-Party } \\
\text { Rule }\end{array}$ & $\begin{array}{c}\text { (13) } \\
\text { One-Man Rule }\end{array}$ & $\begin{array}{c}(14) \\
\text { Electoral } \\
\text { Democracy }\end{array}$ \\
\hline NPP Partisan & $\begin{array}{l}-0.117 \\
(0.081)\end{array}$ & $\begin{array}{l}-0.028 \\
(0.050)\end{array}$ & $\begin{array}{c}-0.533 * * * \\
(0.068)\end{array}$ & $\begin{array}{l}-0.150 \\
(0.133)\end{array}$ & $\begin{array}{c}0.030 \\
(0.140)\end{array}$ & $\begin{array}{c}0.271^{* * *} \\
(0.033)\end{array}$ & $\begin{array}{l}-0.055 \\
(0.055)\end{array}$ \\
\hline $\begin{array}{l}\text { Partisan } \\
\text { Divide }\end{array}$ & $\begin{array}{c}0.308 * * * \\
(0.063)\end{array}$ & $\begin{array}{c}0.924^{* * *} \\
(0.090)\end{array}$ & $\begin{array}{c}0.652 * * * \\
(0.059)\end{array}$ & $\begin{array}{c}-0.207 * * \\
(0.074)\end{array}$ & $\begin{array}{c}-0.753^{* * *} \\
(0.103)\end{array}$ & $\begin{array}{c}-0.559 * * * \\
(0.142)\end{array}$ & $\begin{array}{c}0.055 \\
(0.039) \\
\end{array}$ \\
\hline $\begin{array}{l}\text { Controls } \\
\text { Observations } \\
\text { R-squared }\end{array}$ & $\begin{array}{c}\text { YES } \\
2,626 \\
0.039 \\
\end{array}$ & $\begin{array}{c}\text { YES } \\
2,452 \\
0.125 \\
\end{array}$ & $\begin{array}{l}\text { YES } \\
2,225 \\
0.061 \\
\end{array}$ & $\begin{array}{l}\text { YES } \\
2,261 \\
0.059 \\
\end{array}$ & $\begin{array}{l}\text { YES } \\
2,599 \\
0.070 \\
\end{array}$ & $\begin{array}{l}\text { YES } \\
2,570 \\
0.064 \\
\end{array}$ & $\begin{array}{l}\text { YES } \\
2,584 \\
0.041 \\
\end{array}$ \\
\hline
\end{tabular}


Table B9. Partisan Identities and Ethnicity

\begin{tabular}{|c|c|c|c|c|c|c|c|}
\hline VARIABLES & $\begin{array}{c}(1) \\
\text { Performance } \\
\text { President }\end{array}$ & $\begin{array}{c}(2) \\
\text { Satisfaction } \\
\text { (Economy) }\end{array}$ & $\begin{array}{c}(3) \\
\text { Satisfaction } \\
\text { (Jobs) }\end{array}$ & $\begin{array}{c}(4) \\
\text { Satisfaction } \\
\text { (Education) }\end{array}$ & $\begin{array}{c}(5) \\
\text { Satisfaction } \\
\text { (Health) }\end{array}$ & $\begin{array}{c}(6) \\
\text { Satisfaction } \\
\text { (Crime) }\end{array}$ & $\begin{array}{c}(7) \\
\text { Satisfaction } \\
\text { (Corruption) }\end{array}$ \\
\hline NPP Partisan & $\begin{array}{c}0.987 * * * \\
(0.070)\end{array}$ & $\begin{array}{c}0.883^{* * *} \\
(0.061)\end{array}$ & $\begin{array}{c}0.719 * * * \\
(0.092)\end{array}$ & $\begin{array}{c}0.593 * * * \\
(0.089)\end{array}$ & $\begin{array}{c}0.573 * * * \\
(0.074)\end{array}$ & $\begin{array}{c}0.686 * * * \\
(0.066)\end{array}$ & $\begin{array}{c}0.698 * * * \\
(0.079)\end{array}$ \\
\hline $\begin{array}{l}\text { Partisan } \\
\text { Divide (PD) }\end{array}$ & $\begin{array}{c}-1.824^{* * *} \\
(0.109)\end{array}$ & $\begin{array}{c}-1.522 * * * \\
(0.064)\end{array}$ & $\begin{array}{c}-1.175^{* * *} \\
(0.144)\end{array}$ & $\begin{array}{c}-1.083^{* * *} \\
(0.135)\end{array}$ & $\begin{array}{c}-1.071^{* * *} \\
(0.112)\end{array}$ & $\begin{array}{c}-1.153^{* * *} \\
(0.127)\end{array}$ & $\begin{array}{l}-1.276 * * * \\
(0.075)\end{array}$ \\
\hline Akan/Ewe * PD & $\begin{array}{c}-0.669 * * * \\
(0.139)\end{array}$ & $\begin{array}{c}-0.467 * * * \\
(0.096)\end{array}$ & $\begin{array}{c}-0.529 * * * \\
(0.126)\end{array}$ & $\begin{array}{c}-0.514^{* * *} \\
(0.147)\end{array}$ & $\begin{array}{c}-0.438 * * \\
(0.141)\end{array}$ & $\begin{array}{c}-0.526^{* * *} \\
(0.125)\end{array}$ & $\begin{array}{c}-0.472^{* * *} \\
(0.128)\end{array}$ \\
\hline $\begin{array}{l}\text { Controls } \\
\text { Observations } \\
\text { R-squared } \\
\end{array}$ & $\begin{array}{c}\text { YES } \\
5,128 \\
0.468 \\
\end{array}$ & $\begin{array}{l}\text { YES } \\
5,109 \\
0.389 \\
\end{array}$ & $\begin{array}{c}\text { YES } \\
5,067 \\
0.273 \\
\end{array}$ & $\begin{array}{l}\text { YES } \\
5,169 \\
0.333\end{array}$ & $\begin{array}{l}\text { YES } \\
5,113 \\
0.289 \\
\end{array}$ & $\begin{array}{c}\text { YES } \\
5,096 \\
0.233\end{array}$ & $\begin{array}{c}\text { YES } \\
4,958 \\
0.315 \\
\end{array}$ \\
\hline VARIABLES & $\begin{array}{c}(8) \\
\text { Trust } \\
\text { President }\end{array}$ & $\begin{array}{c}(9) \\
\text { Trust } \\
\text { Parliament }\end{array}$ & $\begin{array}{c}(10) \\
\text { Trust Ruling } \\
\text { Party }\end{array}$ & $\begin{array}{c}\text { (11) } \\
\text { Trust } \\
\text { Opposition } \\
\text { Party }\end{array}$ & $\begin{array}{c}(12) \\
\text { Trust } \\
\text { Police }\end{array}$ & $\begin{array}{c}\text { (13) } \\
\text { Trust } \\
\text { Courts }\end{array}$ & $\begin{array}{c}\text { (14) } \\
\text { Living } \\
\text { Conditions } \\
\text { (absolute) }\end{array}$ \\
\hline NPP Partisan & $\begin{array}{c}1.057 * * * \\
(0.081)\end{array}$ & $\begin{array}{c}0.537 * * * \\
(0.057)\end{array}$ & $\begin{array}{l}1.086^{* * *} \\
(0.082)\end{array}$ & $\begin{array}{c}-0.492^{* * *} \\
(0.088)\end{array}$ & $\begin{array}{c}0.272^{* * *} \\
(0.049)\end{array}$ & $\begin{array}{l}0.163 * * * \\
(0.028)\end{array}$ & $\begin{array}{l}0.560 * * * \\
(0.075)\end{array}$ \\
\hline $\begin{array}{l}\text { Partisan } \\
\text { Divide (PD) }\end{array}$ & $\begin{array}{c}-1.904^{* * *} \\
(0.165)\end{array}$ & $\begin{array}{c}-0.982^{* * *} \\
(0.049)\end{array}$ & $\begin{array}{c}-1.897 * * * \\
(0.107)\end{array}$ & $\begin{array}{l}0.678 * * * \\
(0.096)\end{array}$ & $\begin{array}{c}-0.642^{* * *} \\
(0.075)\end{array}$ & $\begin{array}{c}-0.421^{* * *} \\
(0.053)\end{array}$ & $\begin{array}{c}-1.068^{* * *} \\
(0.127)\end{array}$ \\
\hline Akan/Ewe * PD & $\begin{array}{c}-0.629 * * * \\
(0.149)\end{array}$ & $\begin{array}{c}-0.255^{* * *} \\
(0.046)\end{array}$ & $\begin{array}{c}-0.594^{* * *} \\
(0.102)\end{array}$ & $\begin{array}{c}0.464 * * * \\
(0.088)\end{array}$ & $\begin{array}{c}0.035 \\
(0.122)\end{array}$ & $\begin{array}{l}-0.140^{*} \\
(0.076)\end{array}$ & $\begin{array}{l}-0.115 \\
(0.091)\end{array}$ \\
\hline $\begin{array}{l}\text { Controls } \\
\text { Observations } \\
\text { R-squared } \\
\end{array}$ & $\begin{array}{c}\text { YES } \\
5,166 \\
0.408 \\
\end{array}$ & $\begin{array}{c}\text { YES } \\
5,096 \\
0.185 \\
\end{array}$ & $\begin{array}{c}\text { YES } \\
5,157 \\
0.373 \\
\end{array}$ & $\begin{array}{c}\text { YES } \\
5,080 \\
0.115 \\
\end{array}$ & $\begin{array}{l}\text { YES } \\
5,179 \\
0.105 \\
\end{array}$ & $\begin{array}{c}\text { YES } \\
5,098 \\
0.100 \\
\end{array}$ & $\begin{array}{c}\text { YES } \\
5,217 \\
0.137 \\
\end{array}$ \\
\hline
\end{tabular}


Table B10. Partisan Identities and Ethnicity

\begin{tabular}{|c|c|c|c|c|c|c|c|}
\hline VARIABLES & $\begin{array}{c}\text { (1) } \\
\text { Living } \\
\text { Conditions } \\
\text { (relative) } \\
\end{array}$ & $\begin{array}{c}(2) \\
\text { Economic } \\
\text { Conditions } \\
\text { (Present) }\end{array}$ & $\begin{array}{c}(3) \\
\text { Economic } \\
\text { Conditions } \\
\text { (Future) }\end{array}$ & $\begin{array}{c}(4) \\
\text { Corruption } \\
\text { President }\end{array}$ & $\begin{array}{c}(5) \\
\text { Corruption } \\
\text { MPs }\end{array}$ & $\begin{array}{c}\quad(6) \\
\text { Corruption } \\
\text { Police }\end{array}$ & $\begin{array}{c}(7) \\
\text { Corruption } \\
\text { Judges }\end{array}$ \\
\hline NPP Partisan & $\begin{array}{c}0.297 * * * \\
(0.058)\end{array}$ & $\begin{array}{c}0.806^{* * *} \\
(0.079)\end{array}$ & $\begin{array}{c}0.592^{* * *} \\
(0.075)\end{array}$ & $\begin{array}{c}-0.163^{* * *} \\
(0.020)\end{array}$ & $\begin{array}{c}-0.120^{* * *} \\
(0.013)\end{array}$ & $\begin{array}{c}-0.046^{* *} \\
(0.015)\end{array}$ & $\begin{array}{c}-0.051^{* * *} \\
(0.009)\end{array}$ \\
\hline $\begin{array}{l}\text { Partisan } \\
\text { Divide (PD) }\end{array}$ & $\begin{array}{c}-0.411 * * * \\
(0.064)\end{array}$ & $\begin{array}{c}-1.353^{* * *} \\
(0.120)\end{array}$ & $\begin{array}{c}-0.902^{* * *} \\
(0.210)\end{array}$ & $\begin{array}{c}0.318 * * * \\
(0.049)\end{array}$ & $\begin{array}{l}0.247 * * * \\
(0.042)\end{array}$ & $\begin{array}{l}0.165^{* * *} \\
(0.029)\end{array}$ & $\begin{array}{l}0.151^{* * *} \\
(0.023)\end{array}$ \\
\hline Akan/Ewe * PD & $\begin{array}{c}-0.296 * * \\
(0.114) \\
\end{array}$ & $\begin{array}{c}-0.333^{* *} \\
(0.104) \\
\end{array}$ & $\begin{array}{l}-0.512^{*} \\
(0.235) \\
\end{array}$ & $\begin{array}{l}0.122^{*} \\
(0.055) \\
\end{array}$ & $\begin{array}{c}0.052 \\
(0.046) \\
\end{array}$ & $\begin{array}{c}0.027 \\
(0.038) \\
\end{array}$ & $\begin{array}{c}0.062 \\
(0.046) \\
\end{array}$ \\
\hline $\begin{array}{l}\text { Controls } \\
\text { Observations } \\
\text { R-squared }\end{array}$ & $\begin{array}{c}\text { YES } \\
4,960 \\
0.095 \\
\end{array}$ & $\begin{array}{l}\text { YES } \\
5,183 \\
0.207 \\
\end{array}$ & $\begin{array}{l}\text { YES } \\
4,530 \\
0.289 \\
\end{array}$ & $\begin{array}{l}\text { YES } \\
5,240 \\
0.158 \\
\end{array}$ & $\begin{array}{l}\text { YES } \\
5,240 \\
0.110 \\
\end{array}$ & $\begin{array}{l}\text { YES } \\
5,240 \\
0.026 \\
\end{array}$ & $\begin{array}{l}\text { YES } \\
5,240 \\
0.055 \\
\end{array}$ \\
\hline VARIABLES & $\begin{array}{c}(8) \\
\text { Fear of Crime }\end{array}$ & $\begin{array}{c}\text { (9) } \\
\text { Unfair Gov. } \\
\text { Treatment }\end{array}$ & $\begin{array}{l}\text { (10) } \\
\text { Freedom of } \\
\text { Association }\end{array}$ & $\begin{array}{c}(11) \\
\text { Freedom of } \\
\text { Press }\end{array}$ & $\begin{array}{c}(12) \\
\text { One-Party } \\
\text { Rule } \\
\end{array}$ & $\begin{array}{c}\text { (13) } \\
\text { One-Man Rule }\end{array}$ & $\begin{array}{c}(14) \\
\text { Electoral } \\
\text { Democracy }\end{array}$ \\
\hline NPP Partisan & $\begin{array}{l}-0.085 \\
(0.048)\end{array}$ & $\begin{array}{c}-0.341 * * * \\
(0.051)\end{array}$ & $\begin{array}{c}-0.235^{* * *} \\
(0.053)\end{array}$ & $\begin{array}{c}-0.094^{* *} \\
(0.029)\end{array}$ & $\begin{array}{l}0.177^{* *} \\
(0.068)\end{array}$ & $\begin{array}{c}0.045 \\
(0.036)\end{array}$ & $\begin{array}{l}-0.103^{*} \\
(0.048)\end{array}$ \\
\hline $\begin{array}{l}\text { Partisan } \\
\text { Divide }\end{array}$ & $\begin{array}{l}0.185^{*} \\
(0.090)\end{array}$ & $\begin{array}{l}0.487 * * \\
(0.169)\end{array}$ & $\begin{array}{c}0.184 \\
(0.157)\end{array}$ & $\begin{array}{l}-0.099 \\
(0.112)\end{array}$ & $\begin{array}{l}-0.220 \\
(0.125)\end{array}$ & $\begin{array}{l}-0.124 \\
(0.107)\end{array}$ & $\begin{array}{c}0.086 \\
(0.074)\end{array}$ \\
\hline Akan/Ewe * PD & $\begin{array}{l}-0.021 \\
(0.074)\end{array}$ & $\begin{array}{l}0.270^{* *} \\
(0.115)\end{array}$ & $\begin{array}{l}0.369 * * \\
(0.159)\end{array}$ & $\begin{array}{l}-0.068 \\
(0.139)\end{array}$ & $\begin{array}{l}-0.263^{*} \\
(0.117)\end{array}$ & $\begin{array}{l}-0.160 \\
(0.158)\end{array}$ & $\begin{array}{l}-0.067 \\
(0.038)\end{array}$ \\
\hline $\begin{array}{l}\text { Controls } \\
\text { Observations } \\
\text { R-squared }\end{array}$ & $\begin{array}{c}\text { YES } \\
5,229 \\
0.039\end{array}$ & $\begin{array}{c}\text { YES } \\
4,927 \\
0.104 \\
\end{array}$ & $\begin{array}{l}\text { YES } \\
4,477 \\
0.040 \\
\end{array}$ & $\begin{array}{c}\text { YES } \\
4,517 \\
0.076\end{array}$ & $\begin{array}{c}\text { YES } \\
5,196 \\
0.040 \\
\end{array}$ & $\begin{array}{l}\text { YES } \\
5,161 \\
0.040\end{array}$ & $\begin{array}{c}\text { YES } \\
5,166 \\
0.033\end{array}$ \\
\hline
\end{tabular}


Figure 1. Margin Plots

Figure 1.1. Performance President, 95\% CIs

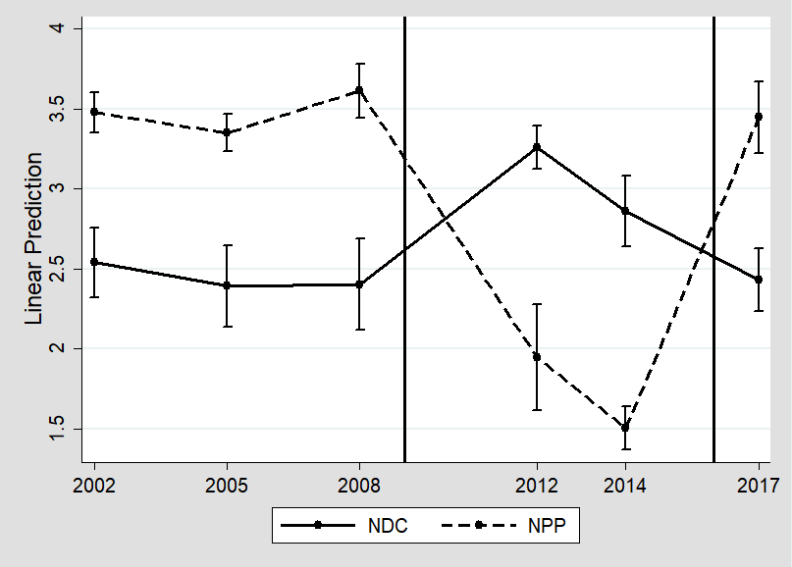

Figure 1.3. Gov. Satisfaction (Jobs), 95\% CIs

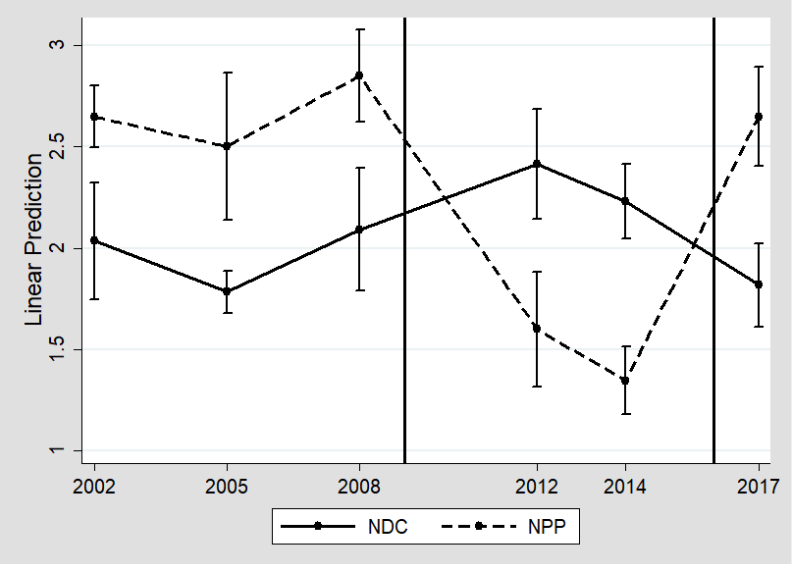

Figure 1.5. Gov. Satisfaction (Health), 95\% CIs

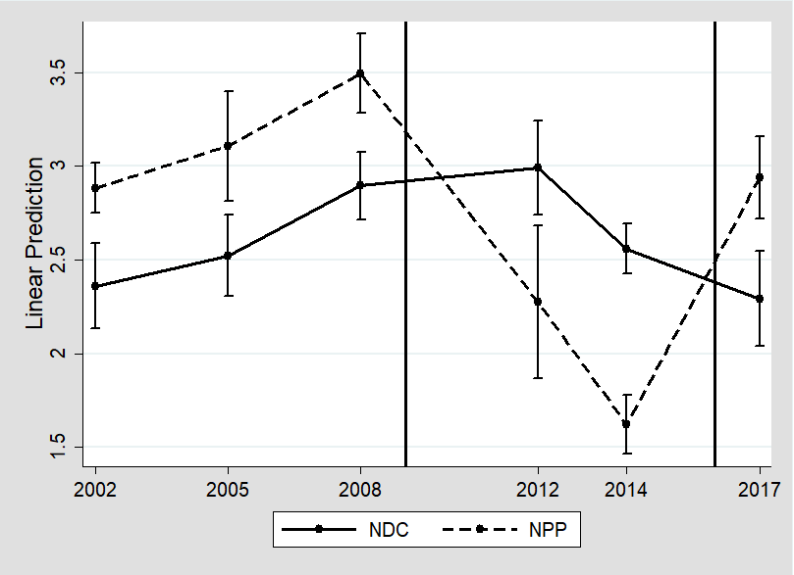

Figure 1.2. Gov. Satisfaction (Economy), 95\% CIs

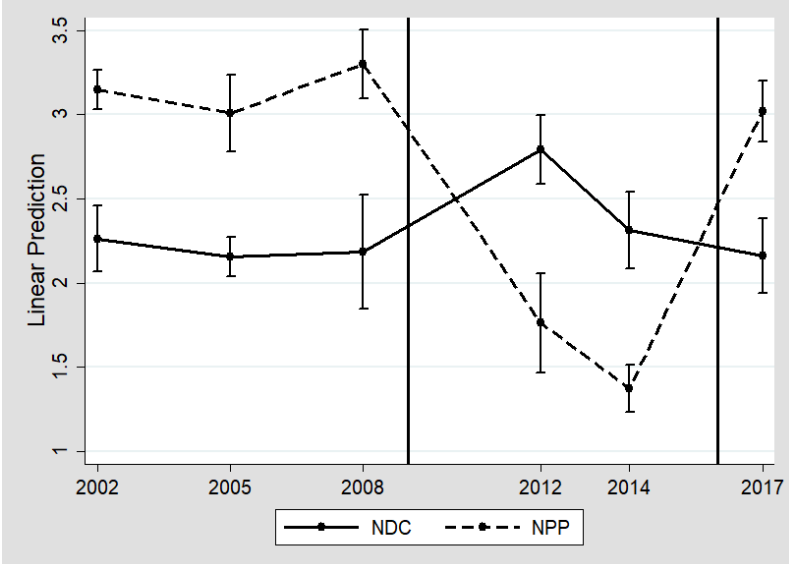

Figure 1.4. Gov. Satisfaction (Educat.), 95\% CIs

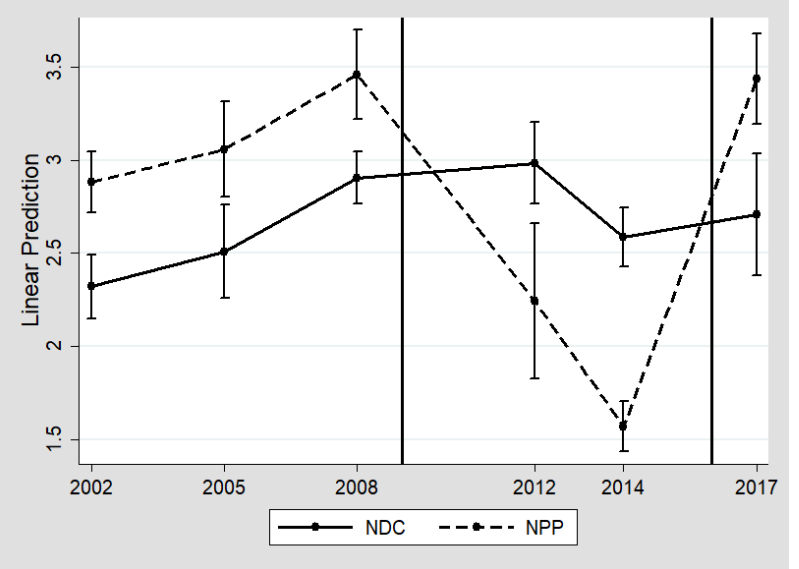

Figure 1.6. Gov. Satisfaction (Crime), 95\% CIs

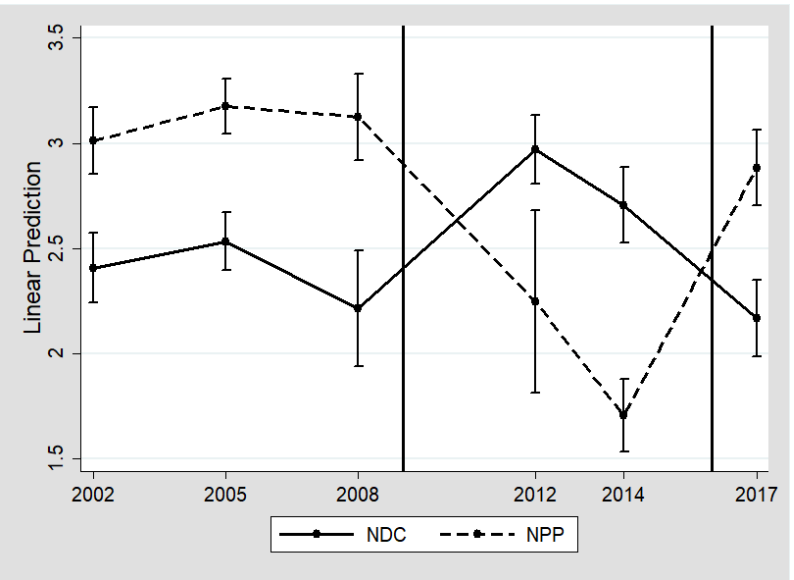

Continued on next page... 
Figure 1.7. Gov. Satisfaction (Corruption), 95\%

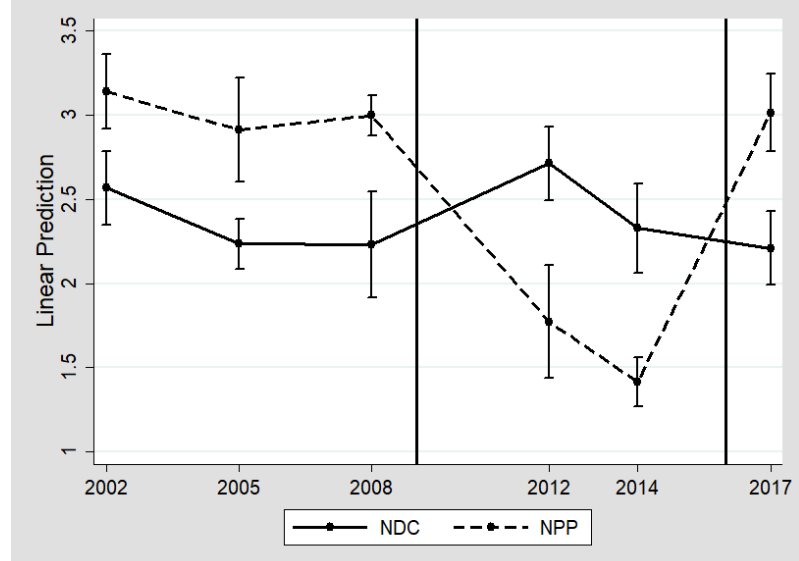

Figure 1.9. Trust (Parliament), 95\% CIs

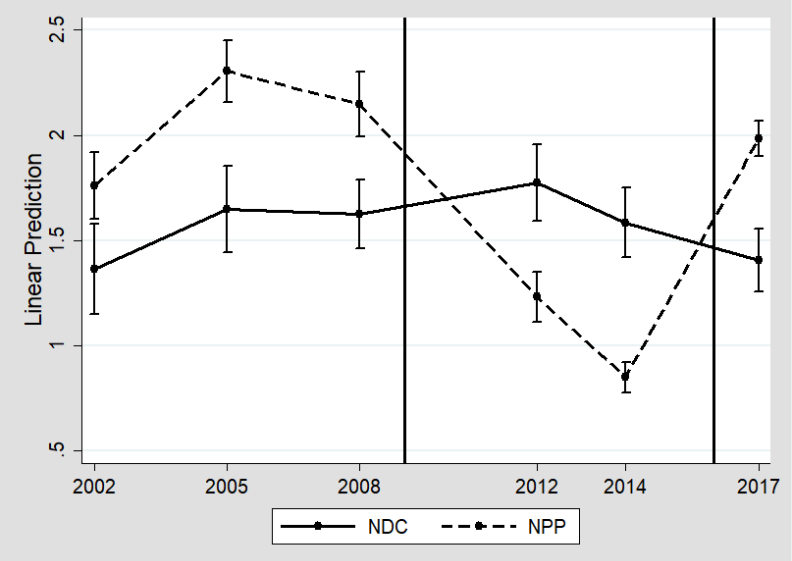

Figure 1.11. Trust (Opposition Party), 95\% CIs

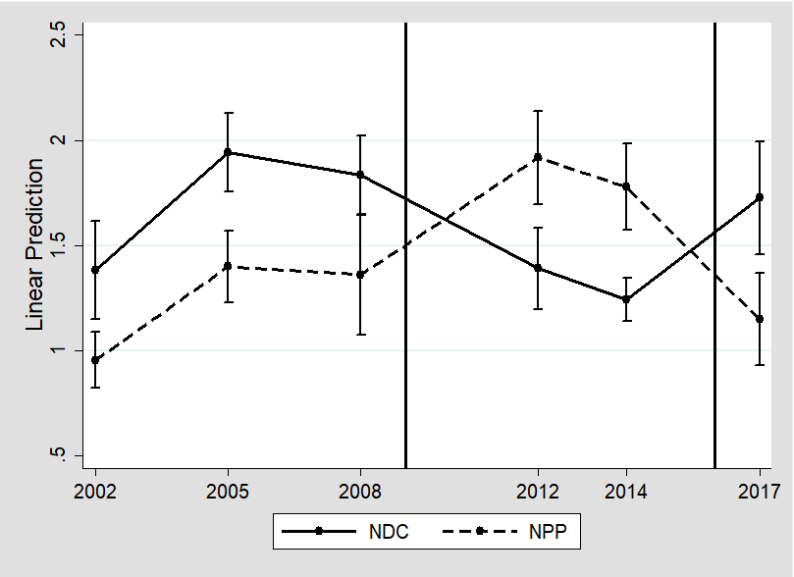

Figure 1.8. Trust (President), 95\% CIs

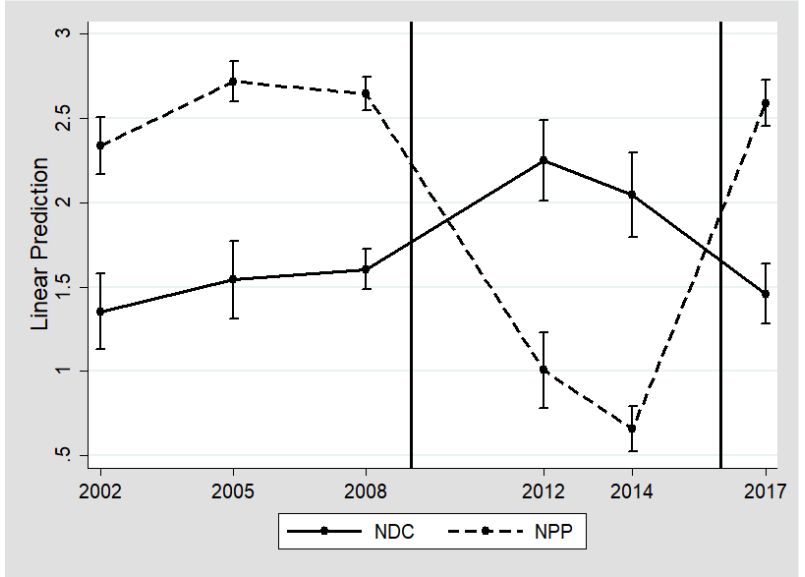

Figure 1.10. Trust (Ruling Party), 95\% CIs



Figure 1.12. Trust (Police), $95 \%$ CIs



Continued on next page... 
Figure 1.13. Trust (Courts), 95\% CIs



Figure 1.15. Living Conditions (relative), $95 \%$ CIs

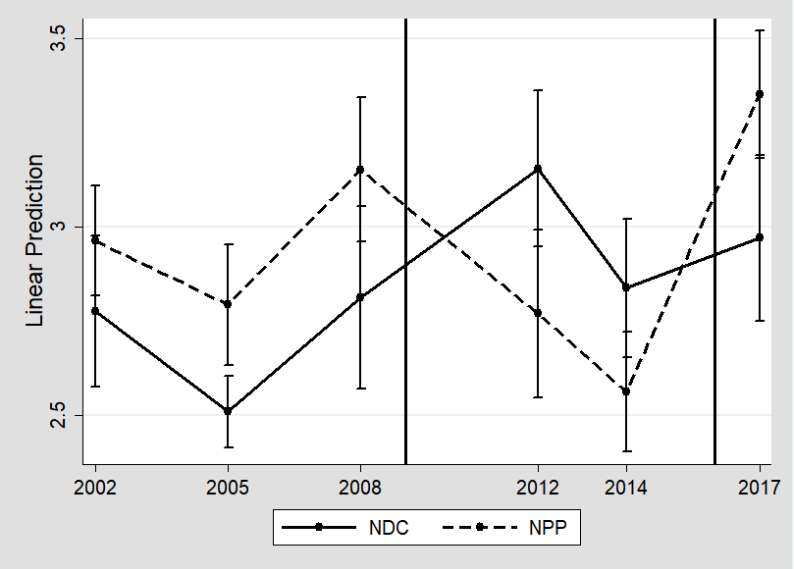

Figure 1.17. Econ. Conditions (future), 95\% CIs

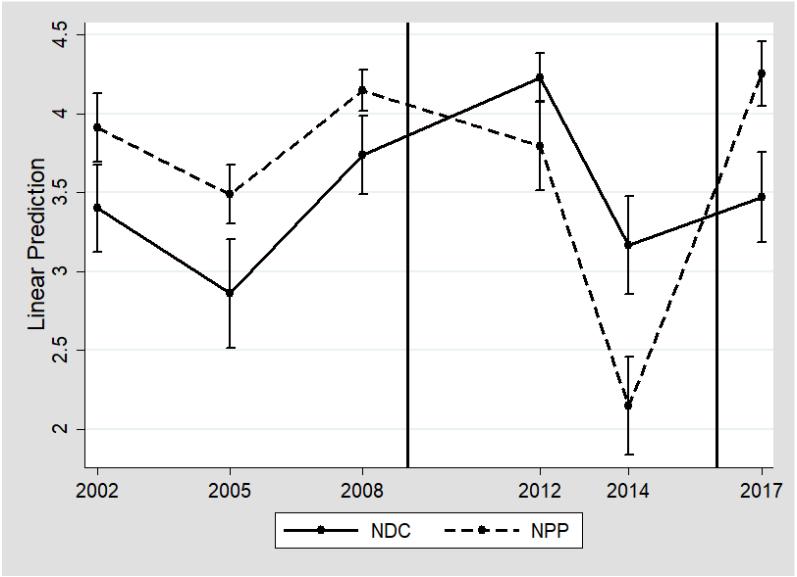

Figure 1.14. Living Conditions (absolute), 95\%

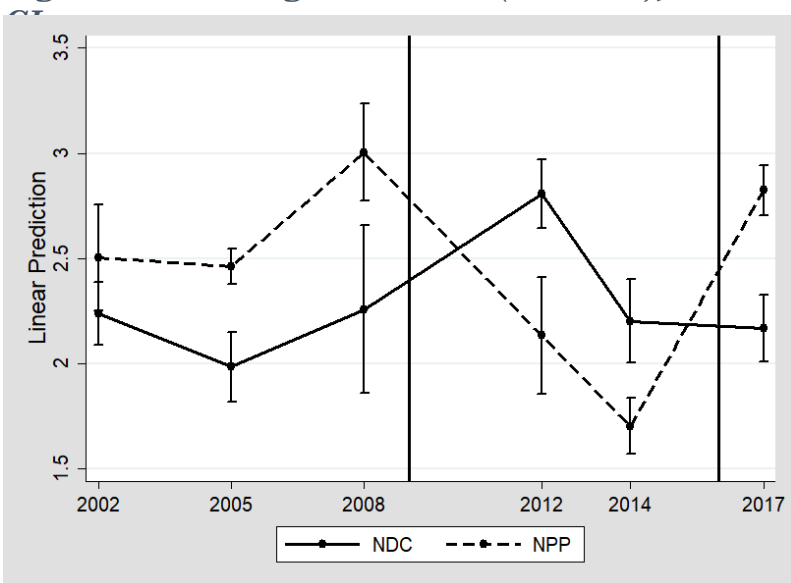

Figure 1.16. Econ. Conditions (present), 95\% CIs



Figure 1.18. Corruption (President), 95\% CIs

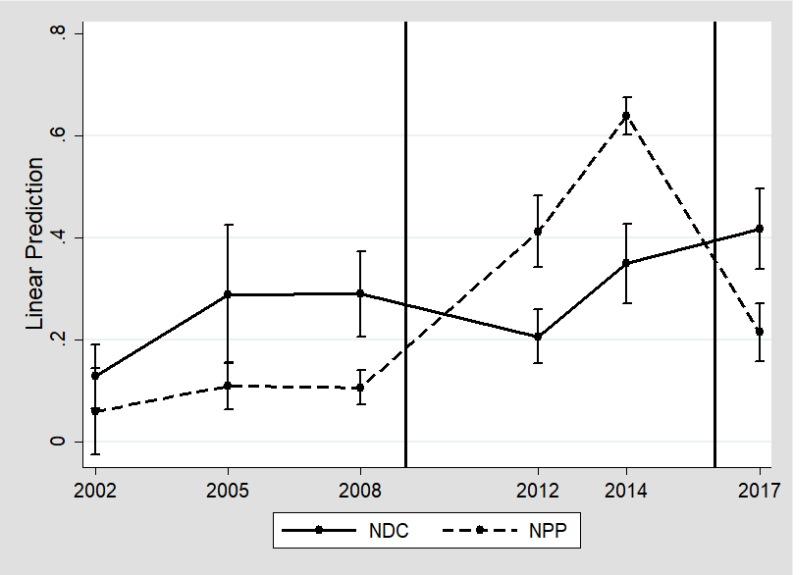

Continued on next page... 
Figure 1.19. Corruption (MPs), $95 \%$ CIs



Figure 1.21. Corruption (Judges), 95\% CIs

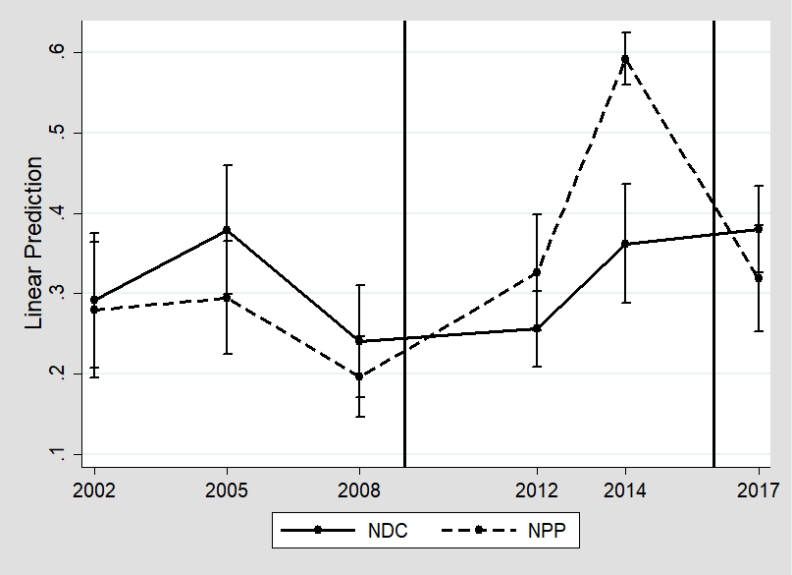

Figure 1.23. Unfair Gov. Treatment, 95\% CIs

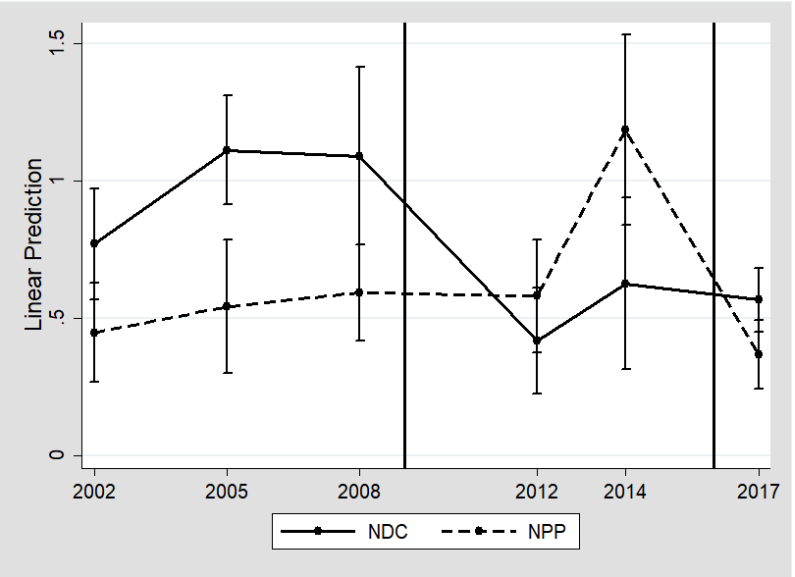

Figure 1.20. Corruption (Police), 95\% CIs

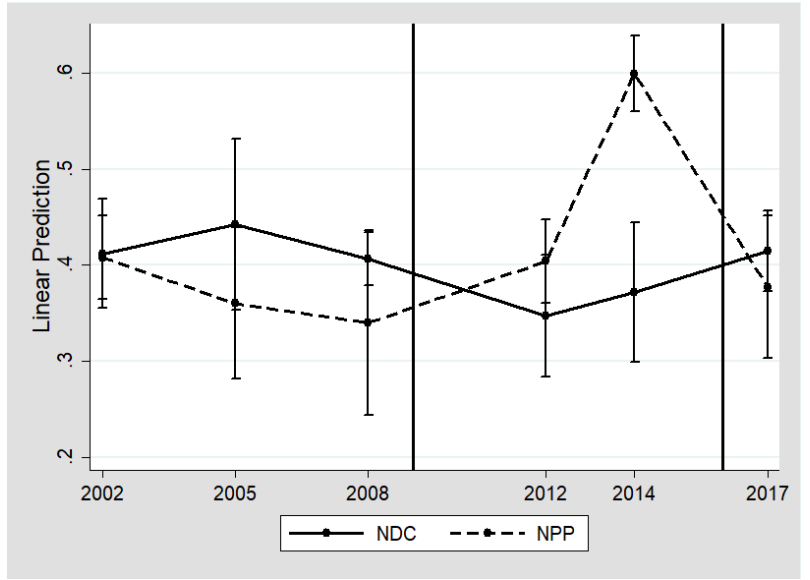

Figure 1.22. Fear of Crime, $95 \%$ CIs



Figure 1.24. Freedom of Association, 95\% CIs

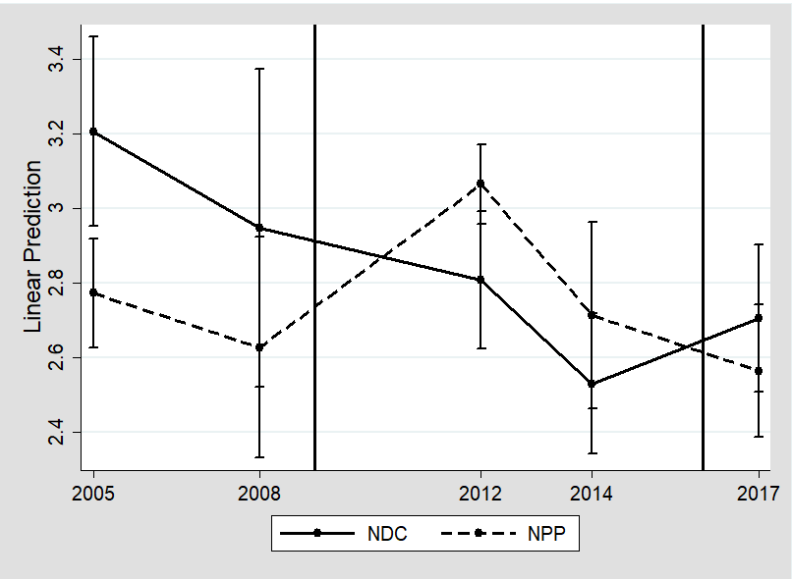

Continued on next page... 
Figure 1.25. Freedom of Press, 95\% CIs

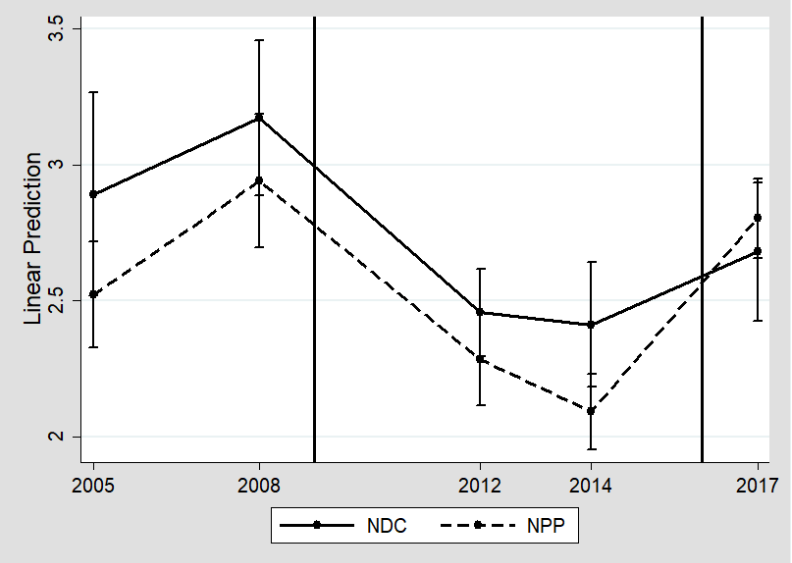

Figure 1.27. One-Man Rule, 95\% CIs

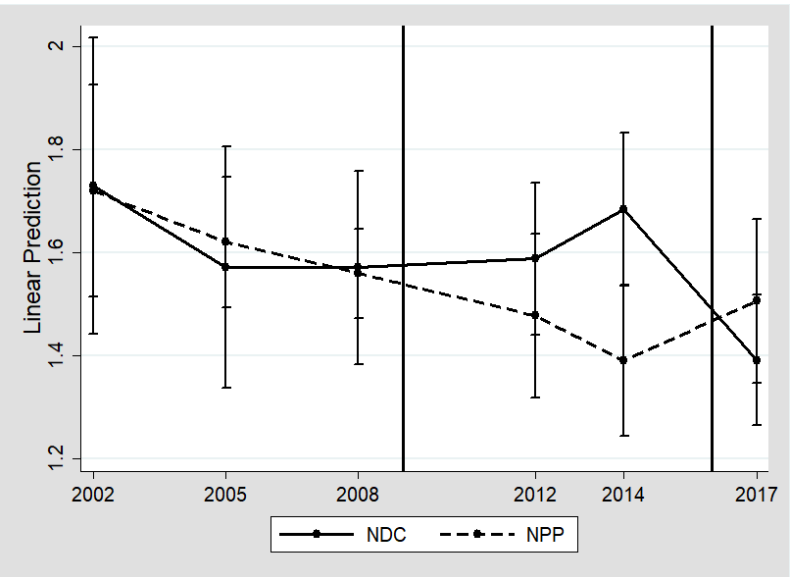

Figure 1.26. One-Party Rule, 95\% CIs



Figure 1.28. Electoral Democracy, 95\% CIs

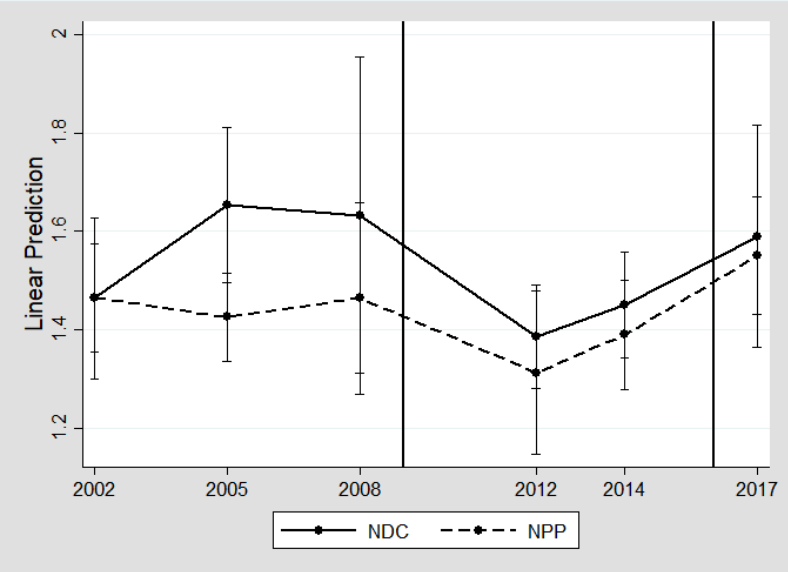




\section{References}

Acemoglu, Daron, Simon Johnson, and James A. Robinson. 2005. "Chapter 6 Institutions as a Fundamental Cause of Long-Run Growth." Pp. 385-472 in Handbook of Economic Growth. Vol. 1. Elsevier.

Afrobarometer. 2014. Round 6 Survey Manual.

Anderson, Christopher J., and Yuliya V. Tverdova. 2003. "Corruption, Political Allegiances, and Attitudes Toward Government in Contemporary Democracies." American Journal of Political Science 47(1):91-109. doi: $10.1111 / 1540-5907.00007$.

Anduiza, Eva, Aina Gallego, and Jordi Muñoz. 2013. "Turning a Blind Eye: Experimental Evidence of Partisan Bias in Attitudes Toward Corruption." Comparative Political Studies 46(12):1664-92. doi: 10.1177/0010414013489081.

Bartels, Larry M. 2002. "Beyond the Running Tally: Partisan Bias in Political Perceptions." Political Behavior 24(2):117-50. doi: 10.1023/A:1021226224601.

Bates, Robert H. 1974. "Ethnic Competition and Modernization in Contemporary Africa." Comparative Political Studies 6(4):457-84.

Bertrand, M., E. Duflo, and S. Mullainathan. 2004. "How Much Should We Trust Differences-In-Differences Estimates?" The Quarterly Journal of Economics 119(1):249-75. doi: 10.1162/003355304772839588.

Blais, André, Elisabeth Gidengil, and Anja Kilibarda. 2015. "Partisanship, Information, and Perceptions of Government Corruption." International Journal of Public Opinion Research edv037. doi: 10.1093/iipor/edv037.

Bob-Milliar, George M. 2012. "Political Party Activism in Ghana: Factors Influencing the Decision of the Politically Active to Join a Political Party." Democratization 19(4):668-89. doi: 10.1080/13510347.2011.605998.

Bratton, Michael, and Robert Mattes. 2001. "Support for Democracy in Africa: Intrinsic or Instrumental?" British Journal of Political Science 31(03). doi: 10.1017/S0007123401000175.

Bratton, Michael, Bhavnani Ravi, and Chen Tse-Hsin. 2011. Voting Intentions in Africa: Ethnic, Economic, or Partisan. 127.

Burgess, Robin, Remi Jedwab, Edward Miguel, Ameet Morjaria, and Gerard Padró i Miquel. 2015. "The Value of Democracy: Evidence from Road Building in Kenya." American Economic Review 105(6):1817-51. doi: 10.1257/aer.20131031.

Cameron, A. Colin, and Douglas L. Miller. 2015. "A Practitioner's Guide to Cluster-Robust Inference." Journal of Human Resources 50(2):317-72. doi: 10.3368/jhr.50.2.317.

Campbell, Angus, Philip E. Converse, Warren E. Miller, and Donald E. Stokes. 1960. The American Voter. Unabridged ed. Chicago [III.]: University of Chicago Press.

Carlson, Elizabeth. 2016. "Finding Partisanship Where We Least Expect It: Evidence of Partisan Bias in a New African Democracy." Political Behavior 38(1):129-54. doi: 10.1007/s11109-015-9309-5. 
Chen, Yan, and Sherry Xin Li. 2009. "Group Identity and Social Preferences." American Economic Review 99(1):431-57. doi: 10.1257/aer.99.1.431.

Cho, Wonbin, and Michael Bratton. 2005. Electoral Institutions, Partisan Status and Political Support: A Natural Experiment from Lesotho. 49.

Conroy-Krutz, Jeffrey, and Dominique Lewis. 2011. Mapping Ideologies in African Landscapes. 129.

Dalton, Russell J., and Steven Weldon. 2007. "Partisanship and Party System Institutionalization." Party Politics 13(2):179-96. doi: 10.1177/1354068807073856.

Dickens, Andrew. 2018. "Ethnolinguistic Favoritism in African Politics." American Economic Journal: Applied Economics 10(3):370-402. doi: 10.1257/app.20160066.

Downs, Anthony. 1957. "An Economic Theory of Political Action in a Democracy." Journal of Political Economy 65(2):135-50. doi: $10.1086 / 257897$.

Elischer, Sebastian. 2012. "Measuring and Comparing Party Ideology in Nonindustrialized Societies: Taking Party Manifesto Research to Africa." Democratization 19(4):642-67. doi: 10.1080/13510347.2011.605997.

Ferree, Karen E. 2006. “Explaining South Africa's Racial Census.” The Journal of Politics 68(4):803-15. doi: 10.1111/j.1468-2508.2006.00471.x.

Fiorina, Morris P. 1981. Retrospective Voting in American National Elections. New Haven: Yale University Press.

Gaines, Brian J., James H. Kuklinski, Paul J. Quirk, Buddy Peyton, and Jay Verkuilen. 2007. "Same Facts, Different Interpretations: Partisan Motivation and Opinion on Iraq." The Journal of Politics 69(4):957-74. doi: 10.1111/i.1468-2508.2007.00601.x.

Gerber, Alan, and Donald Green. 1999. "Misperceptions about Perceptual Bias." Annual Review of Political Science 2(1):189-210. doi: 10.1146/annurev.polisci.2.1.189.

Green, Donald P., Bradley Palmquist, and Eric Schickler. 2004. Partisan Hearts and Minds: Political Parties and the Social Identities of Voters. New Haven, Conn.; London: Yale University Press.

Highton, Benjamin. 2012. "Updating Political Evaluations: Policy Attitudes, Partisanship, and Presidential Assessments." Political Behavior 34(1):57-78. doi: 10.1007/s11109-010-9156-3.

Hodler, Roland, and Paul A. Raschky. 2014. "Regional Favoritism." The Quarterly Journal of Economics 129(2):995-1033. doi: 10.1093/qje/qju004.

Huber, John D., Georgia Kernell, and Eduardo L. Leoni. 2005. "Institutional Context, Cognitive Resources and Party Attachments Across Democracies." Political Analysis 13(4):365-86. doi: 10.1093/pan/mpi025.

Huddy, Leonie, and Alexa Bankert. 2017. "Political Partisanship as a Social Identity." in Oxford Research Encyclopedia of Politics. Oxford University Press.

Jeffries, Richard, and Clare Thomas. 1993. "The Ghanaian Elections of 1992." African Affairs 92(368):331-66. doi: $\underline{10.1093 / o x f o r d j o u r n a l s . a f r a f . a 098639}$. 
Joslyn, Mark R., and Donald P. Haider-Markel. 2014. "Who Knows Best? Education, Partisanship, and Contested Facts: Education, Partisanship, and Contested Facts." Politics \& Policy 42(6):919-47. doi: 10.1111/polp.12098.

Kramon, Eric, and Daniel N. Posner. 2016. "Ethnic Favoritism in Education in Kenya." Quarterly Journal of Political Science 11(1):1-58. doi: 10.1561/100.00015005.

Kranton, Rachel, Matthew Pease, Seth Sanders, and Scott Huettel. 2013. Identity, Group Conflict, and Social Preferences. Working Paper.

Lindberg, Staffan I., and Minion K. C. Morrison. 2008. "Are African Voters Really Ethnic or Clientelistic? Survey Evidence from Ghana." Political Science Quarterly 123(1):95-122. doi: 10.1002/j.1538165X.2008.tb00618.x.

Logan, Carolyn J., Nansozi Muwanga, Robert Sentamu, and Michael Bratton. 2003. Insiders and Outsiders: Varying Perceptions of Democracy and Governance in Uganda. 27.

Lupu, Noam. 2013. "Party Brands and Partisanship: Theory with Evidence from a Survey Experiment in Argentina." American Journal of Political Science 57(1):49-64. doi: 10.1111/j.1540-5907.2012.00615.x.

Mainwaring, Scott, and Edurne Zoco. 2007. "Political Sequences and the Stabilization of Interparty Competition: Electoral Volatility in Old and New Democracies." Party Politics 13(2):155-78. doi: 10.1177/1354068807073852.

Morrison, Donald G., and Hugh Michael Stevenson. 1972. "Integration and Instability: Patterns of African Political Development.” American Political Science Review 66(3):902-27. doi: 10.2307/1957486.

Mozaffar, Shaheen, and James R. Scarritt. 2005. "The Puzzle of African Party Systems." Party Politics 11(4):399-421. doi: 10.1177/1354068805053210.

Ninsin, Kwame A. 2006. Political Parties and Political Participation in Ghana. Accra.

Obeng-Odoom, Franklin. 2013. "The Nature of Ideology in Ghana's 2012 Elections." Journal of African Elections 12(2):75-95.

Olken, Benjamin A. 2009. "Corruption Perceptions vs. Corruption Reality." Journal of Public Economics 93(78):950-64. doi: 10.1016/i.jpubeco.2009.03.001.

Osei, Anja, and Thomas Malang. 2018. "Party, Ethnicity, or Region? Determinants of Informal Political Exchange in the Parliament of Ghana." Party Politics 24(4):410-20. doi: 10.1177/1354068816663038.

Parker, Michael T., and Ronnie Janoff-Bulman. 2013. "Lessons from Morality-Based Social Identity: The Power of Outgroup 'Hate,' Not Just Ingroup 'Love.'” Social Justice Research 26(1):81-96. doi: 10.1007/s11211$\underline{012-0175-6 .}$

Sniderman, Paul M., Richard A. Brody, and Phillip E. Tetlock. 1991. Reasoning and Choice: Explorations in Political Psychology. 1st ed. Cambridge University Press.

Svanikier, Johanna Odonkor. 2007. "Political Elite Circulation: Implications for Leadership Diversity and Democratic Regime Stability in Ghana." Comparative Sociology 6(1-2):114-35. doi:

$10.1163 / 156913307 \times 187423$. 
Taber, Charles S., and Milton Lodge. 2006. "Motivated Skepticism in the Evaluation of Political Beliefs." American Journal of Political Science 50(3):755-69. doi: 10.1111/i.1540-5907.2006.00214.x.

Tverdova, Yuliya V. 2011. "See No Evil: Heterogeneity in Public Perceptions of Corruption." Canadian Journal of Political Science 44(1):1-25. doi: 10.1017/S0008423910001101.

Van De Walle, Nicolas, and Kimberly Smiddy Butler. 1999. "Political Parties and Party Systems in Africa's Illiberal Democracies." Cambridge Review of International Affairs 13(1):14-28. doi: 10.1080/09557579908400269.

Van Gyampo, Ransford Edward. 2012. "The Youth and Political Ideology in Ghanaian Politics: The Case of the Fourth Republic." Africa Development 37(2):137-65.

Whitfield, L. 2009. "'Change for a Better Ghana': Party Competition, Institutionalization and Alternation in Ghana's 2008 Elections." African Affairs 108(433):621-41. doi: 10.1093/afraf/adp056.

Zaller, John R. 1992. The Nature and Origins of Mass Opinion. 1st ed. Cambridge University Press. 